Portland State University

PDXScholar

1987

\title{
German-Czech conflict in Cisleithania : the question of the ethnographic partition of Bohemia, 1848-1919
}

Nicholas Aldorde

Portland State University

Follow this and additional works at: https://pdxscholar.library.pdx.edu/open_access_etds

Part of the European History Commons, Industrial Organization Commons, and the Social History Commons

Let us know how access to this document benefits you.

\section{Recommended Citation}

Aldorde, Nicholas, "German-Czech conflict in Cisleithania : the question of the ethnographic partition of Bohemia, 1848-1919" (1987). Dissertations and Theses. Paper 3663.

https://doi.org/10.15760/etd.5547

This Thesis is brought to you for free and open access. It has been accepted for inclusion in Dissertations and Theses by an authorized administrator of PDXScholar. Please contact us if we can make this document more accessible: pdxscholar@pdx.edu. 
AN ABSTRACT OF THE THESIS OF Nicholas Alforde for the Master of Arts in History presented May 18, 1987.

Title: German-Czech Conflict in Cisleithania: The Question of the Ethnographic Partition of Bohemia 1848-1919.

\section{APPROVED BY MEMBERS OF THE THESIS COMMITTEE:}

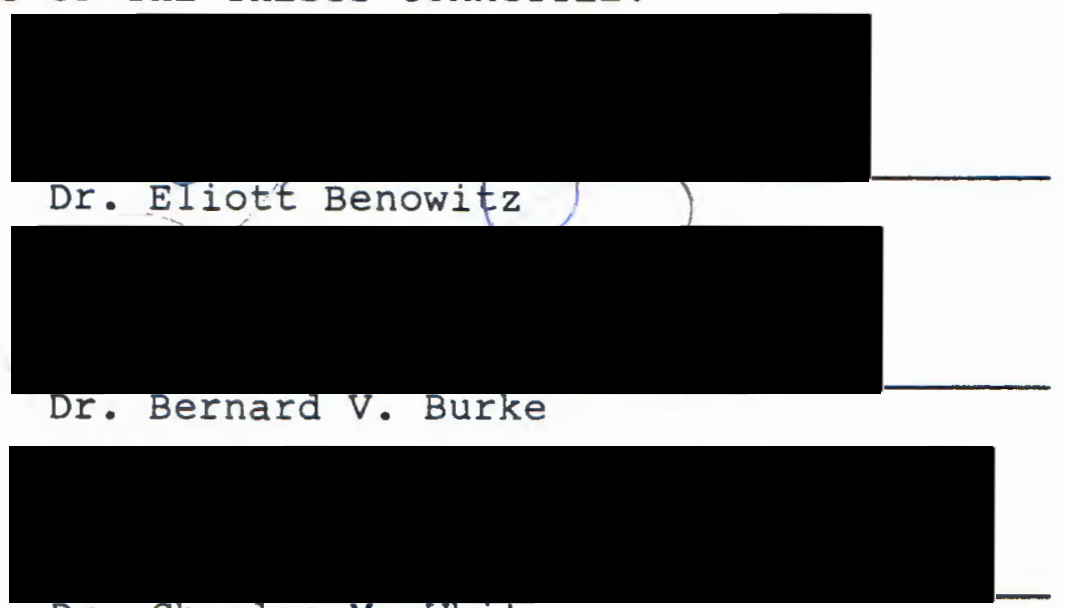

Bohemia, Moravia and Silesia, the former Crownlands of Austria-Hungary which now make up the western half of czechoslovakia, had for centuries a population mixture of 408 German, $608 \mathrm{Czech}$. The national reawakening of the eighteenth and nineteenth centuries pitted the majority Czechs against their German minority master. This, coupled with the social upheavals caused by the industrial 
revolution, brought Czechs and Germans in Bohemia to center stage in the nationality conflict in the multinational Empire.

The universal practice in industrializing nations of the population to shift from rural to the industrial centers was especially significant in Bohemia, for the Germans controlled the cities and large industry as well as the great mining concerns located in the all-German districts of the Crownlands' rim mountain ranges. The sudden influx of Czechs seeking unskilled work heightened job competition and resulted in racial ill-will which eventually found expression in the social and political milieu of the times.

The more radical German elements, of which Bohemia was a stronghold, advocated the complete suppression of czech national aspirations and sought to maintain the German Herrenvolk idea in Cisleithania. Their Czech counterparts regarded the Bohemian Germans as merely invaders or colonists--in any case subject to the czech majority well within Bohemia.

There were, however, moderates on both sides who sought compromise. The German-Bohemian moderate nationalists advocated the administrative partitioning of Bohemia along ethnic lines--Zweiteilung. Czech leaders, with a few outstanding exceptions, rejected Zweiteilung, arguing that the historic borders of the old kingdom of Wenseclas were 
inviolable--externally and internally. The right of the Czechs to maintain their state within the Empire-Staatsrecht--became the Czech battle cry against the German concept of Zweiteilung.

Between 1880 and 1914 one settlement proposal after another was rejected. Chances for a settlement waned as tensions increased.

During World War I Czech exiles in Paris and London, with the blessings of the Entente, pushed for a Czechoslovak independent state (before even radical Czech nationalists had envisioned a state within the Empire). The Bohemian-Germans continued to push for $\mathrm{zweiteilung}$.

At war's end the Czechs proclaimed their republic but the Bohemian Germans refused to recognize Prague and instead swore allegiance to the new Austrian republic, with Vienna in turn claiming German Bohemia.

The autonomous Province of German-Bohemia lasted a stormy six weeks while both sides waged diplomatic war, each seeking the blessings of the victorious Allied Powers.

Slowly, beginning in November 1918, Czechoslovak troops began occupying the German districts, meeting virtually no resistance. By mid-December the Czechs controlled all Bohemia.

By the opening sessions of the Paris Peace Conference the Czechoslav Delegation, with Foreign Minister Eduard 
Benes at its head, could present a diplomatic and de facto fait accompli to the body, which accepted Czechoslovak demands and incorporated 3.5 million Germans along with their $80 \%$ German inhabited area into the new Republic of Czechos lovakia. 
GERMAN-CZECH CONELICT IN CISLEITHANIA: THE QUESTION OF THE ETHNOGRAPHIC PARTITION OF BOHEMIA

$$
1848-1919
$$

\title{
by
}

NICHOLAS ALFORDE

\begin{abstract}
A thesis submitted in partial fulfillment of the requirements for the degree of
\end{abstract}

\author{
MASTER OF ARTS \\ in \\ HISTORY
}

Portland State University 
TO THE OFFICE OF GRADUATE STUDIES AND RESEARCH:

The members of the Committee approve the thesis of Nicholas Alforde presented May 18, 1987.

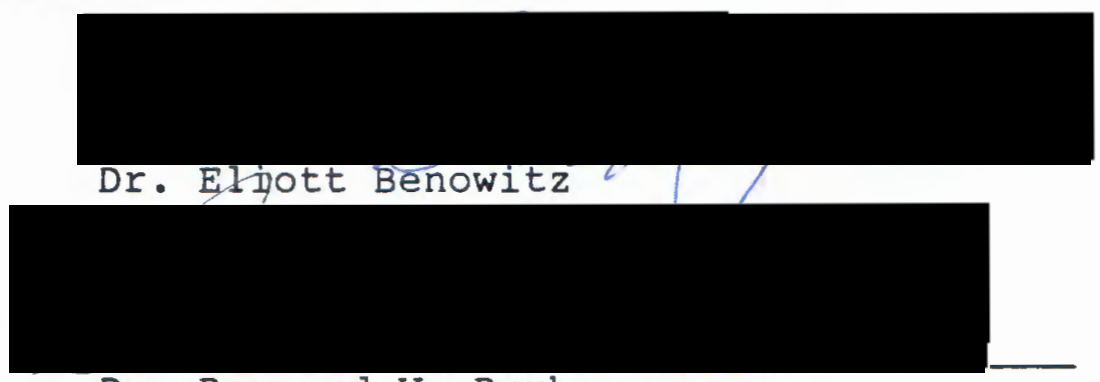

$$
\text { Dr. Bernard V. Burke }
$$

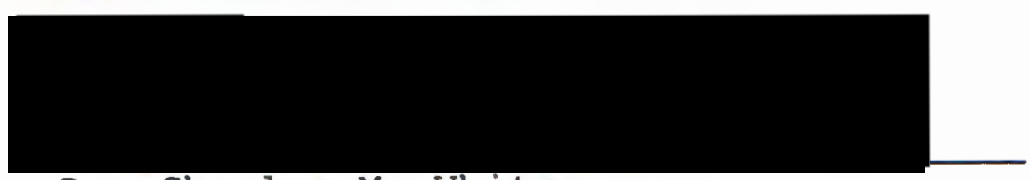

Dr. Charles M. White

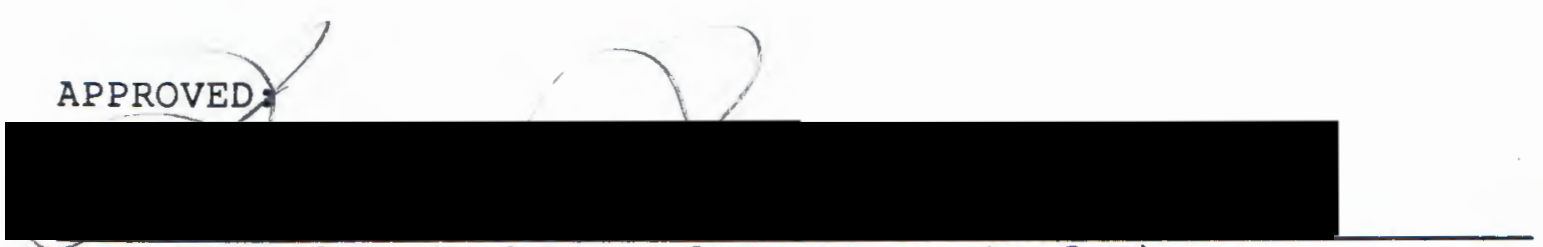

Dr. Bernard V. Burke, Head, Department of History

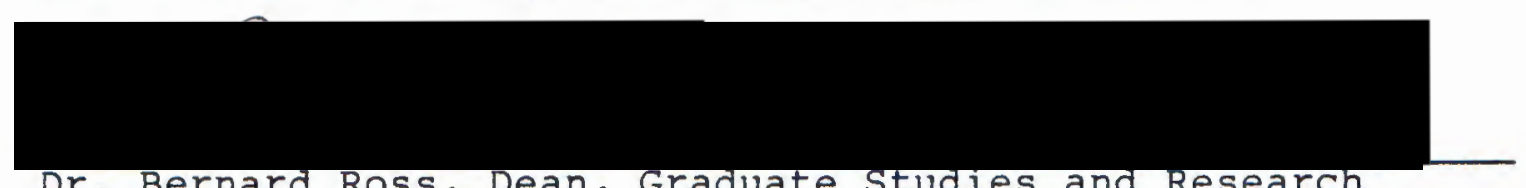

Dr. Bernard Ross, Dean, Graduate Studies and Research 


\section{ACKNOWLEDGEMENTS}

I wish to thank the members of my thesis committee: my advisor, Dr. Eliott Benowitz; Dr. Bernard Burke; Dr. Charles White, and Dr. Louis Elteto.

I also wish to thank Dr. Frank Munk for his invaluable assistance this project. His eye-witness account of the events in Prague in the early part of the twentieth century provided a perspective that the study would otherwise not have had.

I would also like to thank Patrick Bleck for proofreading and editing this work.

I would especially like to thank my wife, Sally, for her inspiration and monumental patience. 
TABLE OF CONTENTS

PAGE

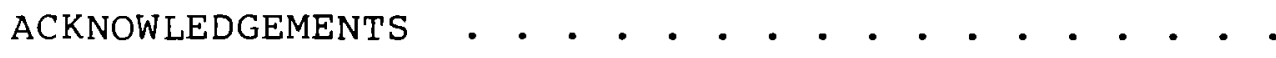
PREFACE

\section{CHAPTER}

I HISTORIC DEVELOPMENT OF THE CZECH-GERMAN CONFLICT • • • . . . . . . . . . . . .

Pre-Habsburg . . . . . . . . . . 1

Austrian Bohemia to 1848 . . . . . 4

Chapter I End Notes . . . . . . 10

I I THE REVOLUTION OF 1848 TO 1890 : POLITICAL AND SOCIOECONOMIC CONSIDERATIONS $\cdot \cdot \cdot \cdot$

Kremsier and Ethnic Partition . . . 15

The Industrial Revolution and Its Social Impact in Light of Geography

Political Backdrop . . . . . . . 25

Neo-Absolutism • • . • . . . . 25

Electoral Geometry

The Iron Ring Coalition

Chapter II End Notes . . . . .

III PARTITION OF BOHEMIA: ZWEITEILUNG OR STAATSRECHT

German Character Under Siege . • • 38

Political Parties and Programs . • 42

The Linz Program . . . . . . . 46

1890 Sprachenverordnurgen . • . • 48 
Badeni-Sprachenverordnungen . . . 50

The Brunn Program . . . . . . 53

The Whitsuntide Program . . . . . 56

The Körber Plan . . . . . . . . 61

The Moravian Compromise . . . . 63

German-Czech Political Position Before 1914 . . . . . . . . . 65

$\operatorname{War}$. . . . . . . . . . 71

Foreign Intervention . . . . . . 80

Collapse . . . . . . . . . . 84

Chapter III End Notes . . . . . 89

IV THE ESTABLISHMENT OF THE GERMAN-BOHEMIAN PROVINCIAL GOVERNMENT . . . . . . . . .

Occupation . . . . . . . . . . 102

Diplomatic Campaigns . . . . . . 105

Last Hopes for German Bohemia . •

The Plebiscite Question . . . .

General Populations' Relation to Their Government Industry's Relation to the GermanBohemian Government

Military Relation to the GermanBohemian Government

Chapter IV End Notes . . . . . . 126

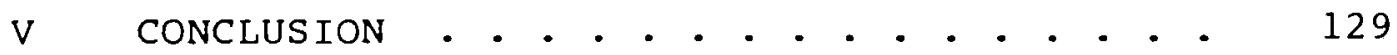

BIBLIOGRAPHY • • • • • • • • • • • • • • • • . • 138

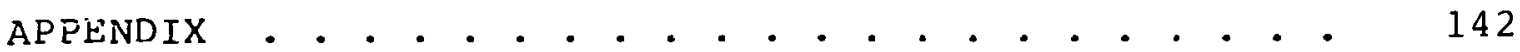


PREFACE

Long before Adolf Hitler made his claims that the socalled Sudetenlands of Czechoslovakia were his own, the idea of the ethnic partitioning of Bohemia had been a heated issue. As early as 1848 proposals along such lines earned serious consideration in the Austrian parliament.

Nowhere in the Austro-Hungarian Empire were two nationalities so pitted against each other as were the Germans and the Czechs in Bohemia. More Western in historical experience and culture than any of their slav sisters, the Bohemian Czechs claimed the same rights to national integrity as did the Bohemian Germans during the nineteenth century. The Czech challenge to Austro-German hegemony naturally resulted in a clash.

This work will examine that clash and the issue of the ethnic partition in Bohemia by concentrating on three principal phases of its development.

First, Czech-German relations from 1848 to 1870 will be examined with special emphasis on the socio-political impact of the industrial revolution on the two nationalities in neo-absolutist Austria.

Secondly, the German-Bohemian reaction to the rising Czech Bourgeoisie and especially to the great Czech 
migration into the all-German industrial areas along Bohemia's mountainous rim will be examined with special attention given to the German attempts to thwart the "Czechification" of all Bohemia by a great variety of proposals aimed at Bohemia's administrative partition.

Lastly, this work will examine the continued GermanBohemian efforts during the First war, their successful but short-lived establishment of an actual autonomous province of German-Bohemia within Czechoslovak-claimed area, and the international reactions during the last months of 1918 .

The term "Bohemia" often applies to the three Crownlands of Bohemia made up of Bohemia, Moravia and Silesia. In this work confusion is spared by referring to the singular Crownland of Bohemia as "Bohemia" or "Crownland of Bohemia." All three in a group are referred to as "the Crownlands," the "Historic Crownlands," etc. 
CHAPTER I

HISTORIC DEVELOPMENT OF THE CZECH-GERMAN CONFLICT

Thomas Garrigue Masarýk, first president of the Republic of Czechoslovakia, gave his inaugural address in Prague on December 22, 1918. In reference to the largest minority group, which made up nearly one-third of the new state's population, President Masarýk said:

- . as far as the Germans in our lands are concerned, our programme has been known for a long time: the territory on which they settled is our territory and will remain so. We have created this State and this determines the constitutional position of our Germans who originally entered the country as immigrants and colonists. [1]

The problems arising from a considerable second nationality within Western Czechoslovakia are older than the empire from which this "successor state" emerged. To better understand the problem and the wide variety of proposed solutions a brief look back to its origins is in order.

\section{PRE-HABSBURG}

Who was there first? The general consensus is that Celtic tribes, referred to as "Boii" by Tacitus, inhabited the Bohemian Basin first [2]. These eventually mixed with 
pre-Christian Germans penetrating from the north around 300 B.C. During the next 800 years the Boii of Tacitus' "Boiohaemum" migrated into what is now Bavaria ". . taking the Celt name which apparently developed into 'Baiowari'" [3], a recognizable ancestor of the name today.

In any case, slavic peoples moved into the resulting vacuum and settled extensively in Moravia and Bohemia. "It is probably correct to regard the period from the sixth to the twelfth century as a period when the inhabitants of Bohemia and Moravia were almost entirely Slav" [4].

During the Christian era the region developed into an ethnically Slav region with a Western orientation. Prague became a bishopric under the Archbishop of Mainz in 973 and, thus, placed the Crownlands of King Wenceslas under extensive German influence. Except for a brief respite--the German exodus during Hussite times--this German influence was to last until 1918 .

From the Church came German clergy and lay professionals. These were followed by German miners who settled in the silver-rich mountainous areas in Bohemia's Randgebiet or rim areas of the country. By the late thirteenth century German artisans, bourgers and merchants had set themselves up in the growing commercial centers of Prague, Brunn, Budweis, Pilsen and others. The attraction was great, for the emigres enjoyed 
extended privileges over the indigenous Slavs [5].

Meanwhile Prague had become the administrative center of the Holy Roman Empire. It boasted its first university, founded by Emperor Charles IV (King of Bohemia, Charles I) in 1348, where Czechs as well as Germans attended and taught.

This "Golden Age" came to a close characteristically due to Czech-German strife centered at the university after Charles' death. As mentioned above, there followed an exodus of German learned men from Bohemia. The exodus was short lived, however.

By the beginning of the sixteenth century Germans were again moving into the Historic Provinces of Bohemia, Moravia and Silesia [6].

This time, however, the heretic Hussite Czech was sharing the Crownlands with heretic Lutheran Germans. A lull in the German-Czech nationality conflict therefore resulted as they faced their common enemy together--the Roman church [7].

The political ties between the Bohemian Crownlands and Hungary predate the inclusion of the Austrian Duchies. The so-called "Personal Union" of the crowns of St. Wenceslas and St. Stephan dates from 1490 with the marriage of Ladislav II, first of the Jagiellon dynasty, to the sister of the king of Hungary. Their issue, Louis II, King of 
Bohemia and Hungary, married a Habsburg. A condition of the marriage contract was that if Louis II produced no heirs, the entire Jagiellon lands would fall into Habsburg hands.

In 1526 at the Battle of Mohács Louis fell, and without an heir. The Jagiellon kingdom, including Hungary, became a possession of the Habsburg Hausmacht and there remained for four hundred years. "This. - marriage set the seal upon the amazing match-making achievements of the house of Habsburg" [8] .

AUSTRIAN BOHEMIA TO 1848

Fifteen twenty-six marks the date when the German miners, merchants and churchmen of the Bohemian Crownlands were no longer foreign invitees, but fellow Germans of the ruling Habsburgs.

The Habsburg "Kings of Bohemia" greatly Germanized the "Historic Crownlands," as they were called. Even the Czech nobility found it necessary to adapt to the new circumstances. But when, in the seventeenth century, German became the official language of government in Prague; and as ever more land was falling into German hands, the Czech nobility, still a viable force, became determined to halt the German advance. "In 1615 the Diet [at Prague] forbade the acquisition of land in Bohemia by anyone who could not speak Czech" [9]. 
This marks the first official designation of nationality based on language in the Crownlands or, put another way, the use of language as a weapon against an opposing nationality. The language question shall eventually become the key focal point in territorial partition movements.

In any case all Czech aspirations were dashed five years later at white Mountain. From 1620 on, the dignity of Bohemia as a kingdom ceased to exist as the Crownlands became a virtual province of Habsburgian Austria.

For this study, the consequences of the Thirty Years War which followed White Mountain are significant, for they mark the virtual disappearance of a viable Czech nobility and its particularist local power. The estates of the erstwhile Czechs so troublesome to the Emperor were confiscated and distributed among those noblemen, Czech and German, upon whom Vienna could rely [10].

An old stratification was strengthened.

- . the general effect of the upheavals of the seventeenth century was to create a state of affairs in which the upper strata were German and the lower were Czech. Thus, the outlines of the social question of the nineteenth century were beginning to appear. [11]

Also, a new wave of Germans ranging from displaced princes to peasants filled the vacuum in the greatly depopulated Crownlands. 
- - the territory inhabited by Germans in Bohemia and Moravia increased during the seventeenth century so that by 1700 the language [and so ethnic] frontiers were drawn for some two hundred years. [13]

With the ethnic borders basically fixed by 1700 the stage was set for the marathon tug of war between Czech and German concerning the ethno-linguistically based territorial partition of Bohemia. (See Appendix, Map 1.)

Two remaining periods must first be examined which contribute to the definition of Czech-German relations. The first is the Enlightenment, which tended to strip both Czech and German power within Bohemia and subjugate them to Vienna; and the second is the romantic national awakening which gave the socially repressed Czechs a feeling of renewed self.

As mentioned above, by 1700 the indigenous powers within Bohemia had been greatly curtailed. The estates general of the Bohemian Crownlands, according to the Vernewerte Landesordnung or "Decree of Denial" of 1627, no longer had the right to elect their own king. They would have their King of Bohemia but only because Bohemia became a hereditary possession of the Habsburgs [13].

During the Aufklärung, a string of "enlightened despots" further reduced the political independence of Bohemia and Moravia by removing their respective Diets from Prague and Brunn and placing their workings within the 
Viennese bureaucracy. In short, there no longer existed decision-making bodies within the Bohemian Crownlands.

The positive side of the centralizing policies, especially under Maria Theresia, was that the new state of affairs fell just as hard on the German estates in the Crownlands as it did on the Czechs. "It was her [Theresia's] policy to reduce the Estates to insignificance" [14]. By so doing she created a kind of "leveling" among the nationalities. She was attempting to create what Professor Seton-Watson refers to as an "a-national empire."

Joseph II brought reforms with his reign. He threw out the Jesuits who had monopolized education in their attempt to root out Hussitism in the Crownlands; the "Robot" system of servitude which had reduced the peasantry to virtual serfdom was officially abolished (though in fact it continued for another century).

These reforms, however, mattered little to the average Czech. The general inertia of the past could not be legislated away so easily. By the end of Joseph's reign in 1790, "Bohemia was totally in the hands of the [Viennese] bureaucrats; it was officially German, tolerantly Catholic and wholly absolute in form of government" [15].

For the nationalities of the Habsburg lands, especially the Czechs, the very reactionary centralizing policies of Vienna provoked a need to be heard. This, coupled with the 
new ideas of equality and liberty embraced in the French Revolution, had a strong effect on all suppressed nationalities of the empire.

A spirit of nationalism was in the air. This, mixed with the rationalist movement of eighteenth century France, Herter's infectious philosophy of the identity of language with nation all had a profound effect on especially the Czechs. The almost forgotten works of Hus, Chelcicky and Comenius were revived and studied [16].

For this study the interpretations of Professor Wiskemann are especially apt.

Out of the Age of Enlightenment.. . was born the Romantic Revival and the spirit of modern nationalism and the Czech-German problem as we know it to-day [1938]. [17]

The greatest contributer to the Czech national revival was Frantiček Palacký. His famous multi-volume work, A History of the Czech People (1836), had much to do with kindling Czech nationalist pride in a past that could stand up to that of the so-called culturally superior Germans. "Palacký hoped that a proper presentation of [Czech] history, notably the epoch of its greatest achievement, would help arouse the nation" [18].

It is indeed ironic and telling of the times that in order to assure publication of his work, Palacký had to write his History of the Czech People in the German language. As 
a matter of fact, Palacký required the patronage of one Count Sternberg, a German, in order to get the work past the Viennese censors.

This was, however, not so odd, for there had been a marriage of convenience between the Czech and German nobility in order to attempt a re-establishment of home rule. This link-up of Czech and German for the common sake of "Bohemianism" was bound to fail, however. The current language theories linking tongue, race and nation were too strong. In the next decades, many Czechs were to look east of their borders toward their slav brethren and identify with the concept of "Slavism," while the Bohemian Germans were to look west toward the Hohenzollern-Prussian brand of "Germanism" and to turn away from the "Rome-influenced" "Slav-infested" Habsburgs. 
1. President Masarýk's inaugural address of December 22, 1918, quoted from J.W. Bruegel, Czechoslovakia Before Munich: The German Minority Problem and British Appeasement Policy (London: Cambridge University Press, 1973), pp. $19-20$.

2. See Tacitus' Germania, Nos. $28,42$.

3. Elizabeth Wiskemann, Czechs and Germans: A Study in the Historic Provinces of Bohemia and Moravia (London: Oxford University Press [under auspices of the Royal Institute of International Affairs], 1938), p. 3.

4. Ibid.

5. Oscar Taszi, The dissolution of the Habsburg Monarchy (Chicago: The University of Chicago Press, 1964), pp. 38-9.

6. Wiskemann, Czechs and Germans, p. 9 .

7. Seton-Watson, Czechs and Slovaks, p. 90.

8. Ibid., p. 86 .

9. Wiskemann, p. 9 .

10. Ibid., p. 10 .

11. Ibid.

12. Ibid.

13. Robert A. Kann, A History of the Habsburg Empire 15211918 (Berkeley: University of Califronia Press, 1974), p. 54 .

14. Seton-Watson, Czechs and Germans, p. 140 .

15. Ibid., p. 161 .

16. Ibid. pp. 161-2.

17. Wiskemann, p. 14 . 
18. Thomas Garrigue Masarýk, The Meaning of Czech History (Chapel Hill: The University of North Carolina Press, compiled 1974), p. 123. 
FROM THE REVOLUTION OF 1848 TO 1890 : POLITICAL AND SOCIOECONOMIC CONSIDERATIONS

The February Revolution of 1848 in France, based as it was on such high-minded notions of fraternity, liberty and equality, became, once imported to central Europe, distorted to accomodate the prevailing social and political grievances whose roots lie in racial rivalries.

For this study three main levels of this rivalry must be considered: first, the position of Austria in relation to the rest of the German Confederation; second, the position of Bohemia within the Danubian Empire; and finally, the conditions within binational Bohemia.

The upheavals of 1848 revived the question last heard in 1815 with the establishment of the German Confederation: Grossdeutschland or Kleindeutschland?

The grossdeutsch idea visualized a united federal Germany with Austria included (excluding Hungary, Galicia and most of Slavonia).

[It] represented the wishes . . of the [German] Austrian liberals and moderate conservatives . . the liberals believed that the German association and Austria's independence as a great power were compatible. [1] 
The kleindeutsch advocates, who foresaw Austria out from the Confederation, found little support among the Austrian German liberals, but they did find it among the Czech nationalists such as Palacký and his son-in-law, Ladislav Rieger, who later became the leader of the old Czech Party.

The Czech nationalists feared that the inclusion of Austria, with her array of non-Germans, in anything other than a confederation would result in the complete submersion of Czech rights in a German sea. Palackȳ and Rieger felt that so long as Germany remained un-unified, Austria could easily remain the presiding member. If Germany were to unite, however, whether under Frankfurt or Prussia, not only would German Austria be relegated to a lower level within the new body, but the slavs would become a real minority whereas in Austria alone they actually represented the majority race (with Galicia and Slavonia attached).

In the first Austrian parliament ever convened the Czech representatives placed themselves to the right of the Liberals who condemned them for not supporting the revolution. The Czech position, however, had more to do with survival as a viable national entity than being anticonstitutional.

The Czechs made up the strongest faction of the right. They were, however, politically committed to the liberal 
constitution concepts of the revolutionary era. On the national question, however, they were vigorous opponents to the militant Germans and condemned Frankfurtism [2] •

The Czech position vis-à-vis the German Liberal is best illlustrated by Palack'́'s refusal to sit at Frankfurt representing Bohemia. He responded by drafting a letter to the Frankfurt body explaining his belief in the necessity of maintaining the Austrian Empire as a great power and condemned the Liberal grossdeutsch idea of its destruction. A Bohemian-German named Hartmann attended in Palackȳ's stead and spoke at St. Paul's church, advocating militarily forcing Bohemia into "Germany" in order to protect Germans in the Sudeten areas [3]. Representative Hartmann's utterances are not only prophetic, they also illustrate a nationalistic bent found in the German settled areas of Bohemia which later would develop into a radical nationalism found nowhere else in Austria.

Not surprisingly, the parliamentary left was predominantly German and pro-Frankfurt. The Germans were also embued with anti-slav sentiment [4].

The interest of the Crown was, of course, the territorial integrity of the Monarchy and the preservation of Austria as a great power. It had to ally itself with a strong faction in Parliament, but which one? The German Liberals, though fiercely nationalistic (considering Germans 
the only Herrenvolk in Central Europe), were anti-Vienna, pro-grossdeutsch and in their radical wing advocated the Habsburg demise. The Center was moderate in its demands. It advocated a continued strong monarchy, but was simply too weak to hold any kind of majority in policy votes. A majority could only be achieved by aligning with the slav right which served as an antidote to Frankfurtism [5].

Therefore, the Czechs found themselves in the role of uneasy champions of the very power that had usurped their royal dignity--the Habsburg crown. Together the "King of Bohemia" and those who no longer had the right to elect him faced off the German Liberals.

\section{KREMSIER AND ETHNIC PARTITION}

Throughout the summer of 1848 the infant Austrian Parliament struggled. Little was accomplished, save the final emancipation of the peasants; and when fresh violence broke out in Vienna in October, Emperor Ferdinand decided to summon parliament's next session in the quieter atmosphere of the small episcopal Moravian town of Kremsier [6]. It was here that the first proposal for an ethno-territorial partition of Bohemia was made.

In January 1849 , a liberal constitution was drafted whose principal designer was the Czech delegation leader, Frantiček Palacký, who proposed that Austria be divided into 
four groups, two of which were a German-Austrian and a Bohemian group.

The significance of this draft is that "[Palackȳ] would have been ready to accept the severance of 'German-Bohemia' from the czech districts" [7]. Palacký was proposing a federation of nationalities, not territories. A later draft included Hungary but still held to the principle of national divisions as opposed to divisions along historical boundaries. He proposed instead of four " . . eight federal groups: (1) German-Austria, including the Sudetian [sic] districts; (2) the Czech lands (Bohemia, Moravia, Silesia, together with Slovakia)" [8]. There was no reason, however, to believe that Hungary would ever hand over Slovakia.

Unable to carry the drafting committee to a federalized national empire, Palacký returned to the only obvious alternative to national federalism--staatsrecht. This principle of the indivisability of the three Crownlands within the "Historic Borders" of the Bohemian King Wenceslas became almost sacred to the Czech nationalists for the remainder of their struggle for statehood. Basically it stood in opposition to the principle of national selfdetermintion and upheld the principle of historic rights. Thus, according to Staatsrecht, the Germans Iiving in the Krönlander were first Bohemians, secondly Austrians, due to 
the right of the Bohemian staat to remain whole.

As mentioned above, unable to carry the drafting committee to a federalized national empire which would have put each nationality on an equal footing,

Palackȳ wavered between. . . the nationalist and the historic solution, a return to 'states' Rights' [historic] being for the Czechs the most obvious alternative to federalism. [9]

The final draft was a necessary compromise between centralism " . . proposed by most Germans, and federalism [either along ethnic or historic-traditional lines] as favored by most of the slavic" [10].

Contrary to Palacký's proposal of the national partition of the Crownlands, the historic borders were to be left unchanged. However, mechanisms were proposed to address the national issue.

The nationally mixed Crownlands [were to be] subdivided into homogeneous districts [Kreise], whose representatives were [to be] added to the Crownland delegation in the upper chamber [in Viennal. The traditional political entities were thus preserved, [historic Crownlands, Staatsrecht] - . and yet a national organization - . was provided. [11]

In March 1849 the Austrian parliament at Kremsier was dissolved, and the constitution was never enacted. The new Emperor, Franz-Joseph, with the aid and under the influence of Prince Felix von Scharzenburg, had militarily gained the 
upper hand and had no need to recognize a parliamentarian document. The constitution that was issued only slightly resembled that of Kremsier and was octroian in nature. The Kremsier constitution is not a dead letter, however. Within this document lies seeds of future struggles.

The very rejection of Palacký's national federation scheme by the drafting committee marks the beginning of the Czech position of staatsrecht. As mentioned above, this doctrine of the indivisibility of the Bohemian Crownlands within their historical borders became so entrenched in the minds of the Czech leaders that it sustained Czech national hopes until its final realization at the Paris Peace Conference of 1919 .

One also finds the embryo of future German-Bohemian demands in the creation of homogeneous Kreise within the historic borders. These groupings of single nationalities were German inventions which served to weaken the province and, thus, the very elements of a federalized Austria [12].

The last thing the Bohemian Germans wanted was a strong democratic Bohemia in an Austrian Federation. By creating semi-autonomous German areas within Bohemia (Kreise), the Germans could maintain their German cultural character, privileged position and politically thwart the Czech notion of staatsrecht (but more on that below).

Liberalism and nationalism both were strong forces 
during the eighteenth and nineteenth centuries, but there were others. Behind the political stage the dynamics of industrialization were beginning to have an impact upon Bohemians in general and upon the relations of Czech to German within the Crownlands in particular. To better understand the social and political consequences of the industrial revolution, a quick survey of Bohemia's unique geography is in order.

THE INDUSTRIAL REVOLUTION AND ITS SOCIAL IMPACT IN LIGHT OF GEOGRAPHY

The ancient kingdom of the Bohemian Crownlands held an interior position within Europe. With the loss of Lusatia and most of Silesia to the Prussians in the eighteenth century, the crownlands became even more centralized and individualized. "The role of the mountain girdle protects the individuality of the region which it encloses" [13]. The area resembles a basin--a relatively flat center with mountains enclosing it on three sides. Palackȳ referred to Bohemia as a Kessel or kettle, the breakup of which would render it no longer useful lobviously a postKremsier reflection of Staatsrecht). As outlined above, the Germans settled in the enclosing mountains, while the czechs inhabited the central basin. The Germans operated the mining industry, while the czechs engaged in agriculture on some of Europe's most fertile land. The capacity of the 
Czech central basins to produce food was matched only by the German-inhabited mountains' capacity to produce minerals. What is here important is that due to the very poor soil in the mountainous areas, the Germans were dependent upon the Czechs for food, while the needs of the Czechs for solid fuels, chemicals, and other minerals could only be satisfied by the Germans.

Bohemia was a textbook example of economic interdependency between two nationalities. With the coming of the industrial revolution, it naturally fell to the German-inhabited mining areas to fill Bohemia's energy needs. The importance of the Randgebiet to modern Austria's economic well being rose sharply.

In the first decades of the nineteenth century mining was still of little consequence to the economy. [In 1819] . . annual production of coal was about 85,000 tons. Only with the introduction of the steam engine and . . railroad did the need for solid fuels take off. [14]

The railroad opened new industrial markets and was soon burning coal while hauling coal, which replaced wood in the homes. "By 1848 annual production was already 600,000 tons; seven years later that. . tripled to 1.8 million tons annually" [15].

It is true that the Germans were not the only beneficiaries of the industrial revolution. The Continental System blockade of the Napoleonic period had given rise to 
new industries everywhere to replace those goods previously imported to Central Europe. Most significant was the sugar beet industry that today still flourishes. One must remember, however, that though Czech entrepreneurs did exist, the great agricultural estates, Grossgrundbesitze, were often in the hands of those who had close ties to Vienna.

Beyond that, processing and shipping of all produced goods, agricultural or otherwise, was invariably dependent upon solid fuels, mostly lignite from the German areas.

- . the consumption of . . coal in AustriaHungary in 1875 [stands as] 15 percent by railroads, 55 percent in manufacturing, much in sugar beet refining, and 28 percent in crafts, services, and households. [16]

It is true also that the largest lignite mines which lay in German Teplitz, Brüx, Falkenau and Komotau of North Bohemia did not match production of the anthracite mines of Czech Silesia until 1871. After that year, however, lignite became the leading coal mined. Indeed, lignite production by 1913 was only second to that of the world's leader--the German Reich [17].

It is worthy of mention that the Crownlands in general were highly favored by the Austrian government. "The Austrians, as a matter of policy, had tended to establish industries in the Czech lands rather than any other part of 
the Empire" [18].

of the Empire in total,

- . the main producer of lignite was Bohemia with 838 followed by Styria with 128 . . hard coal [anthracite] came from Silesia with 468 followed by Bohemia with 278 and Moravia with 148. [19]

The great significance of these figures is that in 1918, truncated Austria will find herself cut off from 858 of her coal sources, which shall have great social and political consequences, as we shall see.

Though Bohemia's industrial boom was hardly unique in nineteenth century Europe, the fact that mining was virtually confined to the districts of one ethnic group was to have grave consequences for the ethno-social stratification of the Crownlands in general, but especially Bohemia, where industry was furthest developed. (Austrian Silesia was also highly developed industrially but the presence of a third, Polish group tended to neutralize ethnic discord.)

Universally, the industrial revolution set certain trends in motion within society. One of these was the tendency for peasants from the countryside to flock to the new urban, industrial centers. In England, Germany and America, for example, this caused great hardships and social inequity. In Bohemia, this was further complicated by ethno-social division. 
The migration of Czechs from the agricultural areas into the all-German areas eventually caused heated conflict which found its expression in a chauvinism practiced by Germans and Czechs alike.

Early Czech migration or "immigration," as the Germans saw it, into German-Bohemia posed little problem, for assimilation was both expected and carried out. The Czech was simply "Germanized" within the factory town--a process not abhorrent to the Czechs themselves, for it had its obvious economic advantages. Besides that, the rather exaggerated nationalism of the German-Bohemians would have it no other way. Czech children would attend German schools; fathers would speak German on the job. Within a generation the Germanization process would be all but complete $[20]$.

Moreover, the Czechs were welcome.

From about 1860, German employers, especially in the lignite area of North Bohemia, were glad to take on Czech labour. . . . It was cheaper (and due to a better diet) it was more virile and therefore more satisfactory for unskilled work. [21]

The next decades, however, saw such an intensification of Czech migration into German areas that German workers were being displaced. The financial crisis of 1873 caused keen competition for jobs. Far from being welcomed, the Czechs were now despised and even blamed for the troubles. 
German-Bohemian leaders, as a result, began calling for the "sealing off" of the German areas in order to prevent what they referred to as the "Czechification" of the pure German character of their Alldeutschgebiete.

At this point it becomes necessary to understand a few basic concepts and to become familiar with certain terms. Convenience is served by referring to certain aspects of the Czech-German conflict as they were heard in the Reichsrat debates and the German press.

The German-Bohemians regarded the Czech doctrine of Staatsrecht (the meaning of which was explained above) as outdated medieval claptrap. Not recognizing its principles, the Germans sought the subdivision of Bohemia, for there the conflict was most acute, into nationally homogeneous Kreise. Each Kreis, of which five or six would exist, was to be made up, as nearly as possible, of German-speaking Bezirke-something akin to an electoral or judicial precinct or parish. Bohemia contained a total of 221 such bodies. The Czechs rejected the notion of partition, or Zweiteilung, for it sought to divide what the Czechs felt indivisible. They further felt that the Germans in Bohemia were simply fellow Bohemians regardless of who sat in Vienna. The Czechs also longed for a fair, democratic electoral system where their majority could set the seal on their destiny as again their own masters [22]. 


\section{POLITICAL BACKDROP}

The political picture in the Empire between 1848 and 1900 can be characterized by the paradoxical definition of an ever-fluxing status quo.

The neo-absolutism of the re-entrenched centralist forces remained intact from the Kremsier rejection until the death of Emperor Franz Joseph, whose reign matches those years exactly. This period is marked with one ministry after another in Vienna unable or unwilling to cope with the problems inherent in a multinational empire.

A settlement amicable to all parties became impossible. Any solution which favored one side was seen by the other as purchased at a cost to them.

To list all proposals and subsequent reactions would be too lengthy and of no practical purpose. Therefore, only those institutions which both endured and affected GermanCzech relations will be discussed.

\section{NEO-ABSOLUTISM}

Professor Dr. Oscar Jaszi defines the return to absolutism after 1848 in terms of the first decade's Minister of Interior, Alexander Bach. 
The 'systeme Bach' agreed with the system of Metternich on three substantial points: One the Germanizing Centralization . . The second - . the extension of the former police and spy system. Third. . the total surrender of the Empire to Catholicism and especially the Jesuits. [23]

Seton-Watson is more succinct. To him the Bach system " - rests upon four posts: 'the soldiers upright, the bureaucrats seated, the priests kneeling, the spies rampant'" [24].

Now the conservative Czech position toward the Schwarzenburg-Bach government in Vienna certainly was not one of blind support, but leaders such as Palackȳ and even less conservative factions led by Pinka and Rieger did see the re-emergence of the conservative monarchy as a bulwark against the real threat to Czech national and political aspirations--the German Liberals. "Palacký . . did not express reaction to the neo-absolutists centralist regime of the fifties so much as reaction to the neo-liberal German centralism of the sixties" [25].

The Austro-German Liberals of the right advocated a Grossoesterreich, a centralized Viennese state, and rejected any notion of federalism, which the Czechs favored. The German Liberal of the left advocated a Grossdeutschland emanating from Frankfurt, rejected federalism on a historical border basis, and wished to lessen the crown while strengthening the parliament. They represented the 
future Social Democrats.

The left's advocacy of a federalism based on ethnic instead of historic lines (not unlike Palackȳ at Kremsier) would seem at least consistent with some Czechs who would drop Staatsrecht for an equitable federalism--especially after the Battle of Windesgrätz in 1866, which all but killed grossdeutsch hopes. Surely the Czechs would fare well within a federalism based on national entities simply by virtue of the Slav numbers within Cisleithania. And they would have, if anything close to a fair electoral system had existed--but it did not.

\section{Electoral Geometry}

The German Liberals came into power in the 1860's and brought with them the Schmerling Curial electoral system which served as an effective device to artificially give the Germans of Cisleithania the majority over the slavs. It is imperative to understand the basic mechanisms of this system in order to fully comprehend its ultimate consequences once the Czech social position began to improve.

The electorate was divided into four curiae, the great landowners or Grossgrundbesitzer, the chambers of commerce, the towns, and lastly, the peasants. Germans dominated the first three, the Czechs the fourth.

Simply put, it took fewer votes from, say, the Grossgrundbesitzer Kurie to elect a favorite candidate, 
usually one of its own, than a peasant to elect one of his. The higher the social status of the voter, the more the vote counted. Added to this was the restrictive franchise based on taxes which, of course, reflected incomes. The ten guilders franchise cut out vast numbers of Czech peasants. Practical examples of the Schmerling system are as follows :

- . in some districts deputies were elected by two or three votes, in others by more than ten thousand votes [and the ten guilder franchise] - . was enough to give Vienna, which then had almost a million inhabitants, no more than 7,400 eligible voters. [26]

For the purposes of this study, the elections of the Bohemian Diet in 1876 are especially revealing.

To the Bohemian Diet [221 seats] the big landowners [a mere handful of people] could elect 70 representatives, the chambers of commerce 15 , the towns 72, the countryside 79. Thus the towns which were German or had a high proportion of Germans had a deputy to 11,600 inhabitants, while the country districts, predominantly Czech--had one to 49,081 inhabitants. [27]

In other words, it took five times more Czechs to elect a deputy to the Diet than it did Germans.

It did not stop here. Until the eighties, only the provincial Diet in Prague, overwhelmingly German, could elect from its ranks the provincial representatives to Vienna. Of the thirty-nine Abgeordneten sent to the 
Reichsrat from Bohemia, Palacký was the only Czech--and he abstained out of protest. "[It] was entirely possible for the administration to control elections arbitrarily and minutely" [28].

But there was a flaw in Schmerling's Wahlgeometrie. It could work to the Germans' advantage only if non-Germans remained at the lower end of the socio-economic scale. Indeed, a shift in the fortunes of the Czech populations could conceivably result in the Curia system actually working against its German designers--and that is exactly what happened.

\section{The Iron Ring Coalition}

The general amelioration of the czech position in the three Crownlands was especially manifest in Bohemia. Indeed, Bohemia represented the social and political vanguard of the Slav world during the last decades of the nineteenth century. Any betterment of non-Germans was viewed with misgiving by those who had so long held an economic monopoly--especially in a world increasingly governed by market competition.

In the second half of the century a Czech 'bourgeoisie' [began to develop] apace to compete with the German employers and financiers who had hitherto extended their power without challenge. [29] 
This was quite a new feature on the Bohemian landscape. This new breed was young, intelligent and upwardly mobile. Moreover, they well realized that in order to get their share they must play the game. They condemned their older colleagues' practice of parliamentary abstention. It was not because they lacked patriotism--indeed their brand of nationalism would soon overshadow that of their older countrymen. It was just that the "New Czechs" practiced a nationalism based on the hard sciences of economics and politics--not on romantic notions of ancient rights or indignant self-righteous indulgences such as parliamentary abstention.

With the arrival of Count Edward Taaffe in 1879 the Czechs returned to Vienna. The Czech delegation was dominated by the "old Czechs," now led by Ladislav Rieger, but within ten years the "Young Czechs" would become the political prime movers.

The Taaffe Era signaled phenomenal changes within Cisleithania. Most important was the collapse of the German Liberal absolute majority, which would never again control parliament.

The strength of Premier Taaffe's government was his creation of the so-called Iron Ring, a coalition of parties which stood in opposition to the German Liberals. The backbone of this coalition lay chiefly in the return of the 
Czechs who, as mentioned above, were beginning to use the Curia system to their own advantage.

Czech cooperation was purchased in basically three ways: First, the crown, which would do almost anything to break the Liberal government, issued a series of Language Decrees in 1880

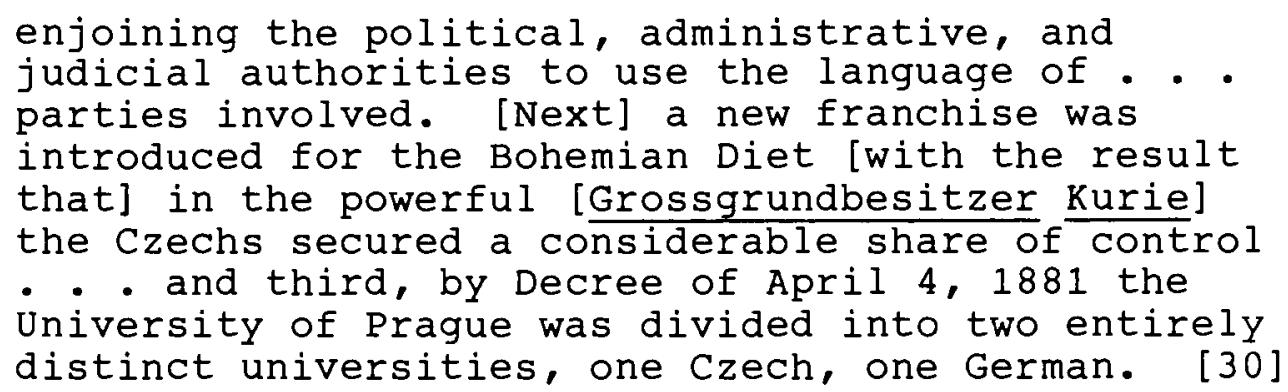

These three K.U.K. decrees were a great blow to the Germans. It may be said that they were struck socially, economically and culturally, in that order.

The first decree is undoubtedly the most important, for language rights of the Czechs in the German districts meant that Germans would be forced to accommodate the evermigrating Czechs. These and later language laws will become the major bone of contention in the battle between

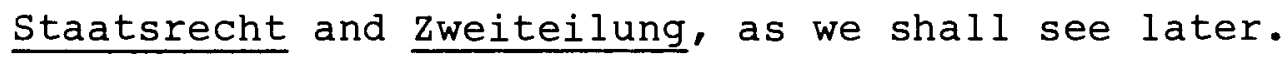

The second decree, that of a lower Grossgrundbesitzer Kurie franchise, allowed those Czechs involved in the strong chambers of commerce curia to advance to the even stronger great estates curia. But, one may ask, how did so many 
Czechs get into the cities' commercial circles in the first place?

In order to take part in the industrial revolution boom, financial banking was necessary. For the Czechs, this was provided by the first Bohemian bank not controlled by Vienna. The Živnostenka Banke, founded in 1868, greatly facilitated Czech industry and allowed many to enter stronger Chamber of Commerce curiae [31].

According to Alois Brusatti, the "Zivnosterka Banku pro Cechy a Moravu became possibly the most expressive symbol of the Czech minority economic emancipation movement" [32]. According to the Schmerling system, economic power and political power were inextricably tied, so that by

- - 1883 the Budweis Chamber of Commerce began to send only Czechs to the Reichsrat [direct parliament elections then possible], and there were tremendous [election] tussles among [Czech and German] businessmen in both Pilsen and Prague. [33]

The Czechs had indeed learned well from the Germans the power of the marriage of political and economic power. What is more, the Germans were now no longer in a position to do anything about the situation in Parliament.

The third decree, of course, had a great impact on the cultural pride of the Czech nation. It is of interest that Professor Dr. Thomas Masarýk was one of the first to be invited to teach at the new Czech university. 
To review the last forty years of the nineteenth century, one sees the German hegemony in Austria reestablished by sham constitutionalism and lopsided rights. The industrial revolution offered opportunities to the Czechs who left the farm and were initially willing to assimilate in the German areas. By the seventies, a new, politically aware Czech bouregoisie was beginning to emerge. It recognized the need to challenge the German political and social monopoly if it was to find a place in the modern world. It did so by using the inequitable electoral system to its own advantage, as well as by developing financial independence from German Vienna. The timely arrival of Count Taaffe and the formation of an "anti-German-Liberal" coalition furthered the betterment of the Czechs vis-à-vis the Germans in Bohemia--and heightened tensions. Soon traditionally German-controlled cities such as Pilsen and Budweis returned Czechs only to the Reichsrat, and German fears for and opposition to the "Czechification" of their areas grew [34].

The Bohemian Germans were naturally alarmed. Their political power was waning. (Bohemia was a stronghold of the German Liberals of the most radical kind). Their devisive electoral system was backfiring, and worst of all the very German character of their mountainous "homelands" was being invaded. Incoming Czechs, far from assimilating, 
began using the new Taaffe Language Decrees to set up Czech "colonies" in German-Bohemia in a deliberate attempt to "take back" Bohemia from the Germans--a process many felt could only be stopped by the ethnic administrative partition of Bohemia. 
CHAPTER II ENDNOTES

1. Kann, A History 1526-1914, p. 256-7.

2. Stanley Z. Pech, The Czech Revolution of 1848 (Chapel Hill: University of North Carolina Press, 1969), p. 170.

3. Wiskemann, p. 24 .

4. Pech, p. 171 .

5. Ibid., p. 172 .

6. Kremsier ( $\mathrm{Cz}$. Kroměříz) was chosen due to its close proximity to olmütz where the royal family had again taken refuge from vienna. It is ironic that once again and not since 1500 an imperial dignity was emanating from the Crownlands of Wenceslas--by Ferdinand I, "King of Bohemia."

7. Seton-Watson, Czechs and Slovaks, p. 192.

8. Ibid., Seton-Watons's parentheses.

9. Ibid., p. 193.

10. Kann, A., History of the Habsburg Empire, p. 311.

11. Ibid., p. 312 .

12. Louis Eisenmann, Le Compromis Autro-Hongrois de 1867: Etude sur le Dualisme (Hattiesburg: Academic International, 1921), p. 130.

13. J. Partsch, quoted from Norman J. G. Pounds, Eastern Europe (Chicago: Adaline Publishing Company, 1969), p. 400 .

14. Alois Brusatti, Die Habsburgermonarchie 1848-1918: Die Wirtschaftliche Entwicklung, Vol. 1 (Wien: Verlag der Oesterreichischen Akademic der Wissenschafter, 1973), p. 151 .

15. Ibid. 
16. Nachum Th. Gross, "Consumption of Coal in AustriaHungary 1831-1913," Journal of Economic History 31 (1971), p. 908 .

17. Alois Brusatti, Die Wirtschafliche Entwicklung Vol. 1, pp. 152-3.

18. Pounds, Eastern Europe, p. 394.

19. Brusatti, p. 153.

20. Wiskemann, p. 39.

21. Ibid.

22. In 1846 the ratio of Czech to German stood at 60 to 40 ; by 1880 the higher $\mathrm{Czech}$ birth rate resulted in a ratio of 63-37. Morovia in 1880 was 71 Czech, 29 German, and Silesia of the same year was 23 Czech, 49 German, 18 Polish. Jan Havranek, "The Development of Czech Nationalism," Austrian History Yearbook 3 (1967), p. 224 .

23. Jaszi, The Dissolution of the Habsburg Monarchy, p. 101 .

24. Seton-Watson, Czechs and Slavs. Professor Seton-Watson is relating a popular saying of the period concerned, hence the secondary quotation marks, p. 197.

25. Robert A. Kann, The Multinational Empire: Nationalism and National Reform in the Habsburg Monarchy Vol. II (New York: Columbia University Press, 1950), p. 108.

26. Kann, Vol. II, Pp. 118-9.

27. Wiskemann, p. 29. Her parentheses. Figures based on Palacký speech to Bohemian Diet, January 1863.

28. Kann, vol. II, p. 119.

29. Wiskemann, pp. 28-29.

30. Seton-Watson, Czechs and Germans, p. 221.

31. Wiskemann, p. 40 .

32. Eduard Maerz and Karl Socher, Wahrung und Banken in Zisleithenia, Alois Brusatti, ed. 


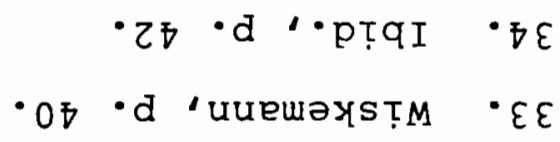

$L E$ 
CHAPTER I I I

PARTITION OF BOHEMIA: ZWEITEILUNG OR STAATSRECHT

GERMAN CHARACTER UNDER SIEGE

As mentioned above, after the sixties and seventies Czechs moving into the German areas, whether German cities within the Czech portions of the country or the Germanoccupied districts along Bohemia's outer edges, were no longer so willing to give up their national heritage as their predecessors had been.

In the last decades of the century a Czech national consciousness led immigrating workers to demand "national equality" such as the use of the czech language in public life and the establishment of Czech schools [1]. These rights, now guaranteed by the Language Laws of 1880 provided the need for educated Czechs who manned the schools and lesser bureaucrats who took posts in municipal administrations in order to guarantee those workers, cobblers, shopkeepers and teachers their legal access to the judicial and administrative rights the Czechs now possessed in Bohemia. Czechs were favored for such posts by the imperial officials due to their bilingual abilities. Of all the manifestations of the new order of things, 
no one aspect caused so much concern to the Germans, especially in the north Bohemian mining areas, as the establishment of Czech elementary schools. Not only did it guarantee a Czech presence in the future of a given area, but the new Language Laws provided Czech nationalists with a tool which they skillfully used to promote the insidious Czech advance into German-Bohemia.

Actually this tool had been on the books since the 1868 Constitution of the Dual Monarchy but no provision was made for its execution, and it simply went unheeded. The Taaffe Laws and the political climate of the 1880's, however, put some teeth into the law.

Article XIX of the Constitution specified that each Bezirk was responsible for the education of its minorities. Further it specified that if forty or more children of a particular nationality lived within a one-half mile radius, the local authority must provide them with a school taught in their language.

The Czech School Union [2], founded in 1880, would organize Czech families together in order to reach the qualifying forty children. If unable to assemble forty, the Union would organize a private Czech School, often financed by the Živnostenka Banke, until forty could be gathered. Once they qualified, the municipal authorities were then obligated to take over the funding of the school, releasing 
the private funds to be used elsewhere in another German town to start the whole process over again [3]. This is not to say that every Czech family was a standard-bearer of Czech nationalism. Their primary reason for settling in the German areas was economical, their primary goal: security for their family. It was chiefly the various Czech and German nationalist "societies" that fanned the fires of conflict.

In addition to the School unions, the German Sportvereine and the Czech Sokols (falcons) represented organized outdoor activities for young men and women. They bordered on the para-military in content and attempted to embue their respective members with a super-nationalism not unlike what one will later see in the Hitler-Jugend. The Sokols were banned in 1915 by Austrian military authorities, and after the Czechoslovak State was proclaimed in 1918 they re-emerged and served as a militia in the early days of the Czechoslovak occupation of German-Bohemia.

There also arose a network of so-called defense leagues from both sides which were based on racial ill will [4]. If the education laws of Article XIX were the tool, it was the Language Decrees of 1880 which provided the muscle to apply that tool. German opposition to the Decrees was not merely based on their ill effects regarding Czech expansion; it went much deeper. The language issue in 
Bohemia was based on the conflict between the two nationalities' divergent concepts of the relation between language and the territory inhabited by those who speak it. First one must distinguish between the two concepts: the language of the land or country--Landessprache--and the language customary in the land--Landesübliche Sprache. Landessprache was any language spoken by 208 of the inhabitants, in this case, Bohemia. Both Czech and German qualified, as approximately $40 \%$ of the Bohemian population used German as its first and mother tongue. Landesübliche Sprache was to the Germans in Bohemia and Moravia the customary language prevalent in any given district [5]. Robert Kann outlined the two positions this way:

The Czechs held that no distinction existed between the two concepts in the Crownlands. The Germans stressed the importance of the distinction . . . The Czechs demanded that the Czech language should on historical grounds be the only official language throughout the two Crownlands, even in German districts. The Germans . . . held that the official language should be only the one customary in any given district--in the German districts, German. [6]

The Czechs' demand for their own language to be the only official language is consistent with staatsrecht and even national self-determination, for they considered Bohemia to be their nation--one nation, one national language determined by the one national majority.

But here the Gleichberechtigung, or equality of both 
languages bode just as ill for the Germans as it would have had Czech indeed been the only official language. Unable to gain recognition of the landesübliche sprache, i.e., German, as the only official language of their all-German areas, the Germans began promoting the administrative separation of Bohemia into a Czech and German part [7]. Such a separation, they felt, would stem Czech expansion and thereby render the Language Decrees of 1880 useless. Time was of the essence for the Germans, for the socalled pure German character in many areas by 1880 already had ceased to exist. It became apparent that if German Kreise were to be established and sealed off from the Czechs, it must be done as soon as possible. "It is estimated that between 1880 and 1900 half a million Czechs migrated to areas that had been 808 German" [8]. And there was little indication of this letting up. (See Appendix, Map 2.)

\section{POLITICAL PARTIES AND PROGRAMS}

The arrival of Prime Minister Taaffe's Iron Ring coalition sounded the death knell of the Austrian GermanLiberals. For years there had been bickering within their ranks chiefly due to divergent opinions as to how they should deal with the rearrangements of society caused by the industrial revolution. 
From the old Liberals, three "socialisms" emerged: National Socialism, Christian Socialism and the Social Democrats.

The Christian Socialists fit somewhere between the conservatism of the church hierarchy and liberal society, a large area indeed. Their active voice was Karl Lueger (1844-1910), who attempted to address the economic grivenaces of the lower bourgeoisie against business and industry [9].

The Christian Socialists were center-oriented and were condemned by the nationalist parties for being too "Slav friendly" in their attempt to address the nationality problem. They, as did the Emperor, eventually became arbiters in the general search for a Bohemian settlement.

The Social Democrats made their first appearance in 1869 as a manifestation of growing industry. It was not until 1889, however, that they had any real power, for it was only then that they were allowed to meet legally once the so-called "Anarchy Laws" were dropped [10].

The early leader of the party was Victor Adler, future Foreign Minister of the First Austrian Republic. His position regarding the Czech-German conflict in Bohemia was simple and reflected the Socialist Weltanschauung in general: The conflict was a social class conflict and not national. The Social Democrats were "international" as 
opposed to "national" and thus proposed that no national privileges be accorded anyone.

The doctrine of the Austrian SDP, chiefly the work of Otto Bauer, Karl Renner and Adler, was consistent with that of Marx and especially of Engels, who labelled the Germans as the vanguard in the Socialist struggle in central Europe and as a bulwark against "Pan-slavism" from Russia [11]. The Social Democrats did not see eye-to-eye with the Christian socialists. They were, after all, vying for the hearts and minds of the newly-enfranchised lower-middle class. However, there was some room for compromise and maneuvering between the two parties. There was no room at all between the Social Democrats and the third major political entity to emerge from the German Liberals in late nineteenth-century Austria--the National Socialists.

The Nationalists represented what in modern jargon would be considered the right, but not the conservative right. That was the territory of the Christian Socialists, which embraced clerical and moderate monarchist views. The National Socialists have been referred to as the "Anti-" party. They were anti-Habsburg (the old Liberal grossdeutsch proponents had found refuge within their ranks); and anti-Jewish, a characteristic they shared with the Christian Socialists but not with the Social Democrats, who had largely a Jewish leadership [12]. 
The founder and leader of the National Socialists was one Georg Schönerer, whom his detractors referred to as Ritter Georg, an allusion to st. George the Dragonslayer. He, as did many nationalist leaders, hailed from the Eger District of German-Bohemia, where the radical National Socialists drew their strongest support and anti-Czech feelings were highest. His followers were "... those Germans whose economic position was most directly threatened by the czech migration" [13]. These included not only those in the mining areas of the German Randgbiet, but often the middle classes in the cities as well.

Many were disappointed with the internationalism of the Austrian Social Democrats. To the displaced German worker, shopkeeper or bureaucrat the facts were before him: the Czechs were not their international brethren, they were their national adversaries. The radical arm of the Nationalists wasted no effort in fanning the fires of this national antagonism.

There were many factions amongst the Nationalists, as among the other parties. Schönerer, Herman Wolf and others represented the radicals who soon formed their own association. In 1885 these radicals formed the extremely nationalistic anti-Jewish Verband der Deutschnationalen, which would win them the admiration of Hitler [14]. 


\section{THE LINZ PROGRAM}

The first officially articulated plan since Kremsier to address the nationality question was the Linz Program. It became the program of Schönerer's pan-Germans in 1895 but only twelve years after its inception. Actually, it was the straw that broke the back of the Liberals and marked their final dispersal in 1883. Its authors include none other than Victor Adler and Georg Schönerer, an unlikely cooperation, but one which well displays the kneejerk reaction of all German parties to the sudden ascendancy of the Czechs during the Taaffe ministry.

The plan ". - advocated the transfer to Hungary, or to an autonomous Galicia, [of] . . all Slavs other than Czechs and Slovenes to make Austria a more German state" [15]. German again was to become the only official language throughout the truncated Austria. Closer ties with the German Reich were encouraged. (The Dual Alliance had by 1883 been in effect three years.)

The Linz Group (Schönerer, Adler, Heinrich Friedjung, Adolf Fishhof) proposed to restore to Austria.

There was a definite grossdeutsch hue to the Linz Program. The idea was to "Germanize" (or re-Germanize) Austria and promote closer ties to her German cousins to the west.

The reasons have as much to do with arithmetic than 
with common culture, however. With the franchise restrictions moving down and the voting power of the czechs moving up, the spectre of Austro-Slavism was beginning to take on substance.

The democratic forces within Cisleithania, especially the Socialists, had always promoted electoral reforms in the direction of an eventual universal sufferage. This, of course, would render the slavs the most powerful race in the Empire due to their real numbers, but not if the Germans could effect the severance of nine million slavs living in Dalmatia, Galizia, Bukovina, Bosnia and Herzegovina. With the loss of the non-German excess baggage, the Germans could replace the backfiring curia system with a fair electoral process with no fear.

The loss of nine million sister Slavs and the reaffirmation of German centralism and the German language was, of course, condemned by the Czechs [17].

The significance of the Linz Program is three-fold. It clearly shows that the ethnic concerns outweighed the political. That is to say, the commonality of Germanism, regardless of political leanings, produced this rather drastic solution to what was collectively perceived as a Slavic challenge to the leading German position within the Empire. It also marks the final break of the republican side of the Austro-German Liberals. The Social Democrats 
would pursue an internationalism couched, however, in the firm belief of the German mission, and the National Socialists would take on a pan-Germanism of the most chauvinistic hues and eventually adopt the Linz plan, which was neither Zweiteilung- nor Staatsrecht-oriented, as their basic platform.

Most German nationalist parties balked at Schönerer and his extremists. The moderate nationalists, Christian Socialists and Social Democrats eventually disowned Schönerer and collectively pursue various varieties of the Zweiteilung approach.

The most significant element of the Linz Plan was that it ". - confirmed [for the czechs] the wisdom of becoming members of a majority in Vienna sufficiently powerful to prevent it from being put into practice" [18].

The Czechs of course were not in a position to call all the shots in Vienna, but they were able to prevent anyone else from doing so. This policy of Czech obstructionism will endure until 1918 and will render parliamentary legislation on the nationality question virtually impossible.

\section{SPRACHENVERORDNUNEN}

In 1890 a provisional Bohemian settlement was reached between Taaffe, the Crown and the old Czechs. The 1890 
Language Decrees called for ". . the duplication of administrative machinery in Bohemia in both languages, and for minority rights in the schools" [19].

Ten years earlier this would have been no small triumph for the Czechs, but by 1890 the old Czechs' seats in Austria's Parliament were diminished by the New Czechs who were much less conciliatory than their colleagues. Indeed, the intransigence of the New Czechs had prevented them from even being invited to negotiations leading to the 1890 settlement.

The Young Czechs repudiated the settlement as nothing less than $\underline{Z}$ weiteilung and condemned the old Czechs for their willingness to abandon staatsrecht and the doctrine of czech being the only official Bohemian language.

One sees the beginnings of each nationality containing two like elements. The old czechs, though waning in power, and the moderate Germans were able to at least negotiate and compromise. The New Czechs, like the National Socialists, were unshakable, and both respectively promoted the Czechification and Germanization of Bohemia.

After 1890 the Crown ". . gave up the idea of reconciliation with Bohemia and may be said to have remained at least latently anti-Czech for the remainder of his reign" [20]. 


\section{BADEN I - SPRACHENVERORDNUNGEN}

Taaffe's fall in 1893 was followed by two years of rule by Grands Seigneurs. In 1895 Franz Joseph appointed Count Casimir Badeni to the Premiership in an atmosphere of intense national conflict within the Empire.

Badeni, as those before him and those who followed, was charged by the crown to finally settle the national problem lest the Empire collapse. Badeni, as those before him, then offered, or rather issued, his proposal. "Count Badeni, by his Language Ordinances of April 1897, for both Bohemia and Moravia, unloosed the greatest storm in modern Austrian politics" [21].

Years of bitter demonstrations followed. Never was any law so universally despised. Clashes in Prague and especially in Egerland between German and Czech were only controlled by constantly calling out the police. "In the notorious 'Baden times' [Badeni zeiten] civil war was perhaps only narrowly averted" [22].

The most amazing aspect of the whole situation is that the ordinances themselves were anything but radical. Indeed, the greater portion of them had been on the books for over twenty years [23]. There was a new twist, however. Badeni inserted within the decree a mechanism insuring its enforcement, and this angered German-Bohemians greatly. Article II dealt with the language qualifications of 
officials. Section I states:

Officials of the Justice and State Administrations as well as Ministers of the Interior [Police], Finance, Commerce and Agriculture placed after June 1,1905 must prove written and spoken knowledge of both languages. [24]

To most Czech officials this meant little, for virtually all were bilingual; to the German officials, however, this was seen as an outrage. It was one thing to provide a translator for a Czech subject in a court of law, for example. It was quite another that all the court officials should learn Czech in order to take their posts-especially in areas totally devoid of czech inhabitants. Needless to say this boded well for Czechs seeking a career in the civil service.

The law was equally unpopular with the Young Czechs around whom the nation had begun to rally and who, by 1898 , numbered more in both the Reicharat and the Bohemian Diet than did the old Czechs.

By 1900 neither accepted the notion of equal rights within the Crownland borders. The Germans, with good reason, feared that Czechs would use the decree to further encroach into German area. The only way the Germans would accept a Gleichberechtingung was by territorial partition.

The Czechs feared that the parity of the languages would have a centrifugal effect on Bohemia and hinder the 
rebirth of the Bohemian State. The recognition of two languages so clearly occupying their own respective areas was seen by many Czechs as the logical precondition to the dreaded Zweiteilung of Bohemia.

Both nations challenged the legality of the laws due to their octroial nature and refused to observe any ruling not a product of parliamentary legislation.

Dr. Seton-Watson described the scene in the Parliament:

The result was frantic . . obstructionism in the Reichsrat. Racial friction degenerated into fisticuffs on the floor of the House, and there was keen competition in catcalls and inkpot-throwing. [25]

Badeni's ordinances were quickly rescinded, though the "times" bearing his name lasted years. In 1898 he and his government fell, to be replaced by Baron Gautsch whose milder language ordinances satisfied no one and were likewise withdrawn. The business of Government had come to a virtual standstill. "All serious business had become impossible [in Parliament], and government could only be continued by the constant use of Paragraph Fourteen [imperial decree]" [26], by an embittered and aging Franz Joseph.

It was in this atmosphere that deputies from all German parties, except Schönerers' "Linzers," began to grasp Zweiteilung as their only hope to maintain the cultural integrity of Deutschboehmen, while the Czechs became deeper 
entrenched in the staatsrecht idea.

The National Socialists and the Badeni-Crown having tried and failed, it was now turn for the somewhat more conciliatory groups to try their hand at breaking the deadlock.

\section{THE BRUNN PROGRAM}

In light of the situation mentioned above, socialist leaders felt that a common German political front was necessary if a solution was to be found to the Empire's nationality problems.

Meeting at Brunn in 1899 the Social Democrats drafted a resolution aimed at findng a compromise with the various Socialist factions in Austria [27].

The Austrian Social Democrats as well as the Christian Socialists and National Socialists however never wavered from the idea of the German Herrenvolk in Central Europe [28].

Adolf Fishhof, one of the principal drafters of the Brunn Program, ". . consistently urged the maintenance of this German leadership through the preservation of the Empire . ." [29]. He went on to say, however, that concessions to non-Germans must be made in order to strengthen that leadership [30].

Fishhof, Karl Kavski, Friederich Austerlitz and others 
saw the whole national struggle in the Marxist doctrinaire view of

- . serving the interests of the ruling class in an attempt to hinder social progress. [Thus]... the regulating of the nationality question within an equal rights framework was in the best interest of the advancement of the proletarian culture. [31]

The Brunn Program, therefore, was the establishment of equal national entities in a democratic federation of nations.

Points 2, 3, and 4 of the final draft give its basic character:

2. In place of historic crownlands . . . ethnically determined autonomous bodies should be created. Their legislative and administrative agencies . . elected by national chambers on the basis of general, equal and direct franchise.

3. All autonomous territories of one nationality should combine to form a nationally homogeneous association, which should have complete selfadministration in national affairs.

4. The rights of national minorities should be protected by a separate law to be passed by central parliament. [32]

Point 5 deals with the temporary designation of German as the language of mediation, but even the most conciliatory Czech saw the danger and rejected it.

The Brunn Program was a scheme for solving the national problems through a complicated system of cultural autonomy based not on territorial units, but on the communities of 
languages. It was designed to fit the intermingling and overlapping of nations and languages within the Empire, especially Bohemia and Moravia.

Simply put it was zweiteilung, something the Czechs would not have, but it goes even deeper than that. Point 2 explains the complete rejection of politico-historical borders, the very soul of Czech demands. Not only in Bohemia but throughout the empire the marriage of people to traditional boundaries was too strong to be dissolved.

Point 4 was rather open-ended and did not really address the issue of the mixed areas where social tension was highest.

If the Brunn Program seems revolutionary yet familiar, it is because it is virtually identical to Palacký's proposal at Kremsier during the Revolution of 1848-9. It is noteworthy that the concept of "Austria" has endured. From Palacký to most Czechs in Parliament in 1918 the belief in a strong cohesive empire persisted.

The Social Democrats' proposal was little more than an official articulation of German concern over Czech expansion couched in the dogma of Marxism and emotional nationalism. Clearly the "autonomous territories of one nationality" were collections of Bezirke to form Kreise, and the "national homogeneous association" refers to the collection of five or six Kreise which would form the autonomous territory of 
German-Bohemia comprising nearly half of the entire Bohemian territory and population.

[The] historical significance [of Brunn] lies in its symptomatic content. It shows just how deep opposition [to staatsrecht] had gone [on the German side] and how far Czech nationalism had seeped into all levels of Czech Society so that any compromise [between Czech and German] became less and less likely. [33]

The idea of an empire of nationalities replacing nations was indeed revolutionary, perhaps too much so [34]. The inability to recognize that the Czechs were not the only ones to place a premium on historic borders within the Empire is reflected by the universal rejection of the Brunn Program in 1900. It also caused a rift among German and Czech members of the so-called "international" Austrian Social Democrats that would result in the creation of a Czech Social Democratic Party five years later which would reject Brunn and uphold staatsrecht.

It is to the Brunn Program's credit, however, that though it was rejected, most German parties embraced many of its integral principals in their own programs. The cry for national self-determination amongst the German-Bohemians was, of course, the most obvious.

\section{THE WHITSUNTIDE PROGRAM}

This program appeared on the scene in June 1899, just 
about the same time as did the Brunn Program. Neither anticipated the other, but both articulated the prevailing moods of turn of the century Austria.

This program was the product of the so-called German opposition parties in Parliament and included the German People's Party, German Progressive Party, Union of Constitutional Landowners, Christian Social Union and the Free-German Union. Whitsuntide reflected the German nationalism of the more radical Linz Program insomuch as it too advocated the severance of the excess Slavic baggage of Galicea, Herzegovina, etc. in order to give Germans a numerical preeminance in Cisleithania. Although far from advocating an Anschluss with the German Reich, it did praise the already twenty year-old alliance with Germany and promoted even closer ties in education and commerce [35]. With regard to the non-German population of the Empire, the Whitsuntide Program was much more conciliatory than Linz. Indeed, the Linz Program wished simply to swallow up the non-Germans, while the Whitsuntide group advocated extending equal rights to all nationalities--but only after the administrative separation from one another, a kind of separate but equal approach. This, of course, reflects the attitude embraced at Brunn but without the universally condemned notion of the dissolution of all historic borders. In short, Whitsuntide advocated the maintenance of the 
old Crownland borders (as per staatsrecht) with national Abgrenzung, or delimitations, within them.

The programs' general demands regarding Bohemia are outlined as follows:

III. Special Fundamental Laws for Individual Countries.

B. Bohemia.

1. National Delimitation. The national [ethnographic] delimitations of the Bezirke which will emanate from the towns is to be carried out. Bezirke are to contain only villages and towns of one and the same nationality. The delimited Bezirke shall be the building blocks of nationally separated administrative areas [Kreise] which shall have their own electoral precincts [Wahlgezirke, usually comprised of three or four Bezirke] for the Bohemian Diet, Imperial Parliament and other representative bodies.

The delimitation of the German and Czech parts of Bohemia.. . will result in each living within their own stamm, or core areas. [36]

The Whitsuntide Program also touched upon the most sensitive areas of German-Czech conflict: "In mixed areas, whether Gemeinde [community], Bezirk or Kreis, both languages have parity [and]. . in all mixed areas schools for minorities are to be built" [37].

On the surface the Whitsuntide Program does not seem wholly unfair. It was, of course, a defensive tactic against the "Czechification" of German Bohemian territory, but it was ready to recognize the czechs as equal partners in their common homeland. It would seem that any Czech 
rejection of such a plan would reveal the true identity of the Czech national aspirations--not equality but dominance in Bohemia. Many saw Whitsuntide as an olive branch held out to the Czechs, the rejection of which would render the conciliatory Germans as the unjustly injured party. The truth, however, is that the program of the German opposition was anything but fair. Interwoven in its content were its selfish motives and its undiminished racial chauvinism.

The main problem revolved around the mixed areas--not the individual rights within them, but exactly which areas were to be considered mixed. The following exposes a rank double standard employed by the Germans in their designation of the national character of a given area.

In the German mining towns where many Czechs worked, the entire family would be counted as "German" due to a system of census-taking that endured until the last Austrian census of 1910. People were counted and nationally designated according to their language of everyday use or Umgangssprache. If a Czech was employed at a German firm he, of course, would speak German on the job and thus was counted as a German. Subsequently, as head of the household, his entire family would be entered on the census rolls as Germans regardless of their origin or what language they spoke at home. Many Czechs argued that instead of the Umgangssprache, the hearth language or the language spoken 
at home, should be the method of determining nationality, but the Germans would have no part of it [38].

The inverse of this practice is displayed in number three of the Special Laws for Bohemia in the Whitsuntide Program: "In mixed areas, such as the Capital at Prague, a parity of both languages shall exist" [39]. The mention of Prague was no random example. "Most Germans believed they had a legitimate claim to Prague and refused to make any concessions to the Czechs who demanded the denial of such a claim" [40]. Some Germans explained the claim as being consistent with Statsrecht and felt that the common capital would help to maintain the unity of Bohemia. Few Czechs were willing to believe that was their intention.

Though the Germans still held control of the Bohemian Diet in Prague--if only by obstructionism--they really represented a mere 58 of the capital's 202,000 citizens in 1900 [41]. Beyond that, nearly 408 of those were Jews claiming German nationality [42]. (Jews were obliged to claim either Czech or German nationality.) Many such Jewish-Germans were prominant bankers and newspapermen and actually disclaimed as Germans by German nationalists. There were proportionately many more Czechs in Vienna than Germans in Prague. The Germans were in effect manipulating demographics to their own advantage. They were exaggerating their presence in Prague, while often unwilling 
to even acknowledge the czech presence in predominately German areas.

In this light the Whitsuntide plan is revealed as a product of the Herrenvolk concept. The Germans sought the dual advantage of maintaining the national character of the German areas and at the same time remaining at the helm of the Bohemian political ship of state. The idea of the Germans claiming two-fifths of Bohemia and parity in what one would assume would be the Czech capital was, of course, abhorrant to the czechs--even to the last vestiges of the more conciliary old Czechs.

The government, though unwilling to meet the demand of Zweiteilung, did reveal a growing tendency to accommodate the Germans over the radicalizing Czechs, which lasted until World War I.

[In] 1899, the aggressive German national Whitsuntide program was issued, and the new Clary cabinet obligingly met its demands to the extent of restoring the language regulations as they had existed [in].. 1880. [43]

\section{THE KÖRBER PLAN}

The last attempt before the war to reach an accord in Bohemia was presented by Premier Ernst von Körber in 1903. Körber enjoyed respect from both sides of the aisle in the Reichsrat. Under his premiership from 1900 to 1904 there was renewed confidence in the machinery of Parliament. The 
excessive use of Paragraph 14 was curtailed; social reforms were initiated, and new commercial agreements with Hungary were made which Körber's predecessors had failed to procure. Dr. Seton-Watson refers to Körber as " . . the most remarkable of Austria's modern Premiers, indeed almost the only one of outstanding merit" [44].

But, alas, relations between $\mathrm{Czech}$ and German leaders had by this time deteriorated to such a degree that even a government in such capable hands failed to dislodge the intense intransigence now exercised by Germans and Czechs alike.

What Körber proposed was not Zweiteilung but Dreiteitung. He attempted to isolate the mixed areas, that is, those areas where the general Czech population geographically met the general German population. Körber hoped that by removing the mixed areas from both Czech and German spheres much tension between the two nationalities could be avoided. This third part of Bohemia would then be self-governing under the auspices of Vienna.

The Körber Program was not unlike the Whitsuntide program in its mechanics, the third division notwithstanding, but it did not carry with it the stridently pro-German attitude of the latter which actually included on the issued draft its own necessity as: "Due to the systematic repression and the ever increasing threat to the 
German race in Austria.. . [45]. Körber's plan was based on simply reaching a settlement between the two nationalities, not the defense of one against the threat of another, as was embodied in former proposals.

The Plan was as good as any other. As a matter of fact, it was still a viable consideration in 1914. But to merely separate the nationally mixed areas from the basically homogeneous areas did not eliminate strife, only isolated it. Just as no one could agree where the ethnic borders should be between the Czechs and Germans in the Zweiteilung form, no one could agree where they should be drawn between, say, German and mixed.

Had the borders actually been fixed, one could assume that the mixed areas themselves would merely have become microcosms of the conflict in general.

\section{THE MORAVIAN COMPROMISE}

The one single success in pre-War Cisleithania was a settlement in Bohemia's sister Crownland, Moravia. The Moravian Compromise of 1906 was the result of simply allowing both nationalities their own fixed seats in the Diet at Brunn. A citizen voted according to his registered nationality. A German could only vote for a German to take a German seat; likewise a Czech. The fixed number of Diet seats for each nationality resulted in eliminating 
competition between the latter. The system was hardly a paradigm of democracy, however. The settlement greatly favored the Germans who represented only $28 \%$ of the population of Moravia in 1900 [46].

The Crownland Diet at Brunn sat a ratio of 73 Czechs to 40 Germans--grossly out of proportion to the population. The curia system survived based on the old estates system. The town Curia was equally divided, but in the country Curia (Grossgrundbesitzern) the Germans held about half the seats, although the actual population was 908 Czech [47]. A fifth universal suffrage Curia was added based on nationality, but it could elect only twenty of the 151 seats at Brunn. The fact that the so-called "Personal system" functioned with little difficulty for ten years shows more the glaring difference between Moravia and Bohemia than it does any merit in the system itself. Such a system as employed in Moravia could never have worked in Bohemia, for the historic national tarditions in Moravia were not as strong as those in Bohemia. Moravia had preserved her clerical conservative tenant-landlord ties and remained almost fuedal in character [48].

Therefore, the feudal landlord-tenant relationship endured in Moravia; it embraced an often clerical conservatism and spurned the nationalist intelligencia which was so successful in Moravia's more cosmopolitan sister to 
the west.

It was, however, a settlement--something achieved precious seldom in pre-War Austria. It is to its credit that the "Personal system" was extended to Bukovina in 1910 where, as in Moravia, it lasted until the collapse of the empire.

Naturally the Crown was pleased; the Germans in Moravia were pleased but the Czech nationalist leaders, such as Dr. Karel Kramár, leader of the Young Czechs, were highly disturbed. Not only was Moravia going her own way by refuting the sacred solidarity of the indivisibility of the Crownlands but internally she had willingly put herself in the pocket of the ruling Germans under the thinnest of democratic pretexts.

\section{GERMAN-CZECH POLITICAL POSITION BEFORE 1914}

The first decade of the twentieth century saw a settlement in Moravia, the abolition of the Curia system for both houses of Parliament (although the Curia remained at the Diet level), followed by the introduction of universal manhood suffrage in time for the 1907 elections, though real strength remained with the crown.

The elections returned the German Social Democrats as the single largest party in Parliament but without an absolute majority, thus rendering Parliament still dependent 
upon coalitions to get anything through.

The Union of the Czechs now held more seats than the German Nationalist Union (Whitsuntide advocates). The Christian Socialists absorbed the clerics to become the largest group, holding 94 seats. But the socialists who alone held 84 had in one year jumped from only ten. The old Feudal Landlord Constitutionalists Conservatives' Union (signators to Whitsuntide) disappeared entirely.

The new Parliament realigned within itself in an attempt to adapt to the new centers of political power. Consequently there were divisions among divisions, which represented every political hue. "In total there were 28 factions, a truly representative picture of the national and political diversity in current Cisleithania" [49].

There then began a spirit of mutual cooperation between Slavs who, now that the Curias were dissolved, were the most numerous race in Parliament. The solidarity of all Slavs in Vienna was, on the whole, ineffective. One must remember that the Crown still was in ultimate control.

- . though there [now] was a democratic parliament, there was no parliamentary government. The ministers received their posts from and were instructed by the crown and were not responsible to Parliament. [50]

Though Parliament was radically democratized, it was still as weak as ever before the crown. 
The elections of 1911, the last of the Austro-Hungarian Empire, again returned the Socialists as the largest single party. Due to a return to pessimism brought on by the universal disapproval of the continued ineffectiveness of government regarding the nationality problems, the German political middle collapsed and split its alliance between the Nationalist Socialists and the Social Democrats, causing a polarization of power in Austrian politics in general. The Czechs abandoned the Germansim of the Austrian Social Democrats in 1905 and formed their own party which rejected the Zweiteilung of Brunn and joined in the allCzech ranks of Staatsrecht. The czech political parties came under the leadership of Thomas G. Masarýk, who founded the Realist Party in 1900, and Karel Kramár, who headed up the Young Czechs.

Masarýk spurned the overtly racial overtones of "Slavism" and instead embraced the Western rationalist philosophies of Locke and Hume. He saw for the future Czech state a kind of liberal democracy along the lines of that in the United States. Masarýk and his closest collaborator and student Eduard Beneš were to be the first among the few who visualized a Czechoslovakia completely independent of Vienna. One must remember that those who longed for the resurrection of a Czech state never considered that it would not belong to an Austrian federation centered in Vienna. 
Masarýk's Realist Party never returned more than three seats in the Reichsrat [51]. He was, however, very much respected by his colleagues and counterparts.

Unlike Masarýk, Karel Kramár looked to the East for Czech salvation. His abiding belief in the pan-slavic movement actually foresaw the possibility of a Russian Grand Duke wearing the crown of st. Wenceslas and continued to do so until the Bolshevik revolution of 1917 whereupon he joined the "Westerners." He was looked upon by the Habsburg Crown as a rebel, and his Young Czechs were regarded as revolutionaries. Franz Joseph referred to the Young Czech victory in the 1898 elections where they returned more seats than their older more conservative old Czech colleagues as an example of the stupidity of the voting peasants and an indication of the revolutionary aims of the Young Czech leaders [52]. The disdain the Viennese government had for Kramár would become more apparent during the war with the military clique in charge.

Masarýk's Realists were allied with the new Czech Social Democrats who, by 1907 , were the largest single Czech political party, with Kramár̆'s Young Czechs close behind. Masarýk and Beneš during the first decade of the new century both held that Zweiteilung may indeed be the Bohemian answer and that staatsrecht was of dubious merit-rather curious convictions coming from the future president 
and Foreign Minister of the future independent Czechoslovak Republic.

- . there arose individual voices from the Czech camp that were nearer . . to the German point of view. [Benes]. . . saw the Zweiteilung as not so bad and, in contrast to the Czech party's standpoint vis-a-vis the Kreise Abgnenzung, [he] saw the basis for a solution to the national question. [53]

Dr. Benes' opinion was published in 1908 in Le Proplem Autrichien et la Question Tcheque, in which he states:

Certainly the struggle could never be completely avoided but by $Z$ weiteilung many causes of strife could. The state [Austria] would leave the problems . . to the individual national territories . . and would insure only law and order. . . [Each] nationality would . . develop its own resources, and the state would favor none over the other. [54]

As for the concept of Staatsrecht he goes on to say in the above-mentioned work,

It responds excellently to the wishes and dreams of the Czechs but has little practical and realistic value. . . One cannot seriously think of establishing a Czech state if one-third of the population [Germans] is ready to fight with all means. [55]

Beneł was obviously much influenced by his mentor, Masarýk, who felt that the Czech cause did not rest on the principle of Staatsrecht but simply on the notion of free people living as equal Austrians [56]. The most important point 
Masarýk makes here is the "equal nationalities" idea, for it does not necessarily mean "national autonomy."

Masarýk's position approached the German demands for national separation and thus offered a compromise, asking for recognition of the bilingual character of all public agencies in Bohemia but not demanding that officials have a command of both languages [57].

It was just that "bilingual character" that Germans saw as the greatest threat to the unilingual character of their German areas. Masarýk's watered down "Badeni Laws" had no appeal whatsoever to the $\mathrm{Zweiteilung}$ proponents. What good would Zweiteilung be if that which Zweiteilung was devised to thwart was allowed to go on unabated--namely the bilingualism and Czech incursion from which the Germans wished to isolate themselves?

Negotiations between those Czechs and Germans who were still willing to hope for a solution had been reduced to a game of first moves. That is, the Czechs were willing to discuss national partition of Bohemia only after language laws allowing both languages equal footing throughout all Bohemia had been accepted--these, in essence, were Masarýk's terms. The Germans demanded the administrative partition first which, of course, would render such language laws superfluous, for the autonomous nature of the German areas would simply, and legally, close their borders to Czech 
immigrants and parity of the Czech language [58].

Among the Germans was an Imperial deputy from Aussig in North Bohemia, who, for the same reasons as Masarýk and Beneš, bears mentioning. Deputy Dr. Rudolf Ritter Lodgman von Auel was a member of the German Progressive Party, one of the German opposition parties. Lodgman, however, rejected $\underline{z w e i t e i l u n g}$ and refused to $\mathrm{fix}$ his name on the Whitsuntide Plan which many Progressives endorsed.

He was of the opinion that the czech settlements in the German areas, based as [they were] on overwhelming economic necessity, would not be stymied by Gebietsabgrenzung. [59]

Lodgman, who spoke Czech without an accent and was in closer touch with Slav feelings than his colleagues [60], believed the "Personal Principle" of the Moravian Compromise much more acceptable than territorial delimitation. Ironically, just as Masarýk and Benes did not object to Zweiteilung but would later become the personification of Staatsrecht, Lodgman, who opposed Zweiteiling, was to become governor of the German-Bohemian Autonomous Province in late 1918 and thus the very personification of zweiteilung.

\section{WAR}

In December 1914, shortly before his departure to go abroad for the duration of the war, Dr Masarýk had a conversation with his friend, former Prime Minister Dr. 
Ernst von Körber. The following dialogue shows the new Czech-German relation war had created.

Masaryk: If Austria wins, will Vienna be capable of carrying out the necessary reforms?

Körber (decidedly): No! Victory would strengthen the old system, and a new system under the young . . Archduke Charles . . ., would be no better than the old. The soldiers would have the upper hand - . and they would centralize and Germanize. It would be absolutism with parliamentary embellishments.

Masarýk: Will Germany be wise enough to make her ally adopt reforms?

Körber: Hardly. [61]

Benes and Masarýk now wholeheartedly supported the maintenance of the historic borders of Staatsrecht with the added claim to Slovakia. Not even Palackȳ had claimed both, and Masarýk's contradictory demands of the lands of st. Wenceslas plus the Hungarian region of Slovakia, which had never belonged to the Bohemian kingdom, would result in later criticism. Benes and Masarýk further rejected federalism and embraced complete independence.

As for what Masarýk envisioned for the Germans of Bohemia, he had by April 1915 stated,

It may seem to be a paradox, but it is only on the principle of nationality that we wish to retain our German minority . . [ [for] in no country are two nationalities so intermixed and interwoven as in Bohemia. [62] 
This is, of course, not entirely true. Mixed areas did indeed exist but the overwhelming majority of German territory was at least 908 German [63], even by later Czechoslovak accounts.

Kramár̆, who still looked to the East, " . . was content to wait passively until the tramp of Cossack hoofs should sound on the streets.. . of Prague itself" [63].

Kramár, as did other more radical Czech leaders who remained in the Empire, had little choice of action. He did not have the luxury of espousing such dangerous ideas as those in self-exile in Paris, London and later Washington, D.C. (Benes et al) [64].

There were many like Kramár who believed in the legendary "Russian Steamroller" which, of course, never came. Instead, the first two years of war were marked by substantial victories for the Central Powers. This had a great effect on German Nationalists, especially in Bohemia, where warring Austria found her most avid patriots.

The victories in the East brought on a heady aura of confidence that played into the militant radical Germans' hands. About this time Friedrich Naumann's book, Mitteleuropa, appeared; it advocated the establishment of a German-controlled Central Europe from the Baltic to Bulgaria. "Mid-Europe will have a German nucleus, will voluntarily [!] use the German language, which . . is 
already the language of intercourse of Central Europe" [65]. It was the resuscitation of the old grossdeutsch idea as embodied in the Linz Program of 1883.

The combination of military victories, Naumann's book and the activities of certain Czech leaders (Kramár and others had been tried for treason and were awaiting execution in 1915) brought forth an opinion that a settlement of the nationality problem in Bohemia need not necessarily be in agreement with the Czechs. More and more the idea was pushed to the front that the problem should be solved by a decree from above favoring, of course, the German position [66].

The upshot was the notorious Easter Demands of 1916, signed by individuals of all Austro-German political parties. Lodgmann, who was making headway in the direction of a settlement based on the "Personal System," refused to sign the Demands. If he felt the Whitsuntide Plan to be radical, he certainly would not fix his name on a resuscitated Linz Plan.

All the old demands were there: German as state language, separation of Galicia and ". . [the] insistence on the legal recognition of German political, cultural and racial superiority" [67].

The old Emperor naturally refused to sign what was tantamount to an abrogation of the 1867 constitution, which 
gave, albeit unspecified, guarantees of equality to all nationalities. Neither would his heir, Emperor Karl I, who donned the imperial crown in December 1916, after FranzJoseph finally passed on.

The actual situation for Czechs in Bohemia was not so very different from that proposed by the Easter Demands. Public meetings were banned; the sokols were outlawed by military officials; and by 1917, 20,000 citizens had been arrested, including businessmen and political leaders no longer enjoying parliamentary immunity (the Reichsrat had been closed since the outbreak). "Until the change of regime which followed the death of Francis Joseph, the Czechs were as completely muzzled as any people in Europe" [68].

With the arrival of Karl to the throne, momentous developments occurred. Aware of the deepening resentment in Bohemia as elsewhere, Karl took on a mantle of appeasement, both at home and abroad. He reconvened the Reichsrat in May 1917 and appointed Dr. Ernst von Seidler, a Social Democrat, to the Premiership. Karl gave amnesty to Kramár and others who returned to Prague to a hero's welcome. He put out peace feelers toward France through his brother-in-law, Prince Sixtus of Parma, the disclosure of which prompted Wilhelm II to demand reaffirmation of Austro-Hungarian loyalty to the Dual Alliance [68]. 
The opening of Parliament on May 30,1917 , saw the return of a very confident and outspoken Czech leadership, especially since Bohemia had become a virtual Czech interment camp.

Only a week earlier 150 prominent czech leaders in politics, business, education and the press had drafted the Manifesto of the Czech Parliamentary Club. It " . demanded a federal state of free and equal national states and the union of all Czechs and Slovaks" [70]. This brazen official demand for slovakia followed close on the heels of the French reply to President Wilson's request for an articulation of Allied war aims. The French government's response included " . . the liberation of Italians, of Slavs, of Roumainians [sic] and of Czecho Slovaks from foreign domination" [71]. Benes and other Czech exiles in Paris were doing good work.

With the inclusion of Slovakia the German nationalists correctly felt that $\mathrm{Czech}$ demands now rested upon a contradictory basis of historic rights in their claims to all Bohemia and national self-determination in their claims to slovakia. If logically applied, the latter should leave the German-Bohemians free to unite with Austria--or even Germany. The former, though certianly allowing the Czechs to claim German-Bohemia, would not allow claims to slovakia. The Czechs were accused of wanting it both ways while not 
granting either way to the Germans [72].

The manifesto was defeated all down the non-Czech line. To the Hungarians it was tantamount to a declaration of war [73]. Seidler's proclamation of a federalized Austria, which was merely an updated version of the Brunn Plan, was also rejected. Parliament proved no more effective than it had been before the war.

There was one difference however. Parliament provided a forum for the discontentment of the various nationalities in the Empire as before 1914, but now the Allies too were listening. They were beginning to understand the potential value in the exploitation of national grievances.

Understanding the potential value of friends in the Entente camp, the Czechs missed no opportunity to let their views be known in Parliament. This "talking through the window" was chiefly for the benefit of the outside world in general. They wanted the Entente to know that a potential ally awaited within the confines of the Austro-Hungarian empire. This also afforded a way of talking to their kinsmen in exile [74]. By late 1917 the Czech kinsmen were talking back.

Eduard Benes sent word from his Paris-based Czechoslovak National Committee that the time was right for a general statement emanating not from the floor of Parliament but from Prague itself. 
Therefore, on January 6, 1918, through Benes' prompting," . . writers, all the Czech delegates of the Reichsrat and the Diets of the Bohemian Crown . . " [75] convoked at Prague a convention which drafted the so-called "Epiphany Manifesto."

Besides the fact that it came from Prague and that "Czechoslovakia" be allowed to attend the peace conference, there was nothing really new in its demands. Incidentally the Czechs at home were still proposing a Czechoslovakia within an Austrian Empire. Their actions were provocative, but not seditious.

The significance of the Manifesto is not so much its content nor even its intention, but the response it solicited from the German-Bohemians who were prompted to their strongest action to date.

Prior to 1918 there had been some talk of enacting an autonomous German-Bohemian Province answerable to Vienna but having nothing to do with Prague. By mid-January 1918 it had become audible from German Bohemian delegates in general. First they condemned the present Ministry of Seidler when they announced to the press

- that the United German Bohemian Deputies [excluding Social Democrats] were going into opposition to the seidler cabinet. They further announced that they no longer have confidence in $\mathrm{Dr}$. Seidler and the Ministerium due to their wavering and weakness in regards to the Czechs. [76] 
They ended with an attack on the government that every household in the agriculturally poor German areas could understand. [Our actions are] ". . also due to the ongoing economic crisis and the government's failure to keep promises to procure much needed coal and food stuffs" [77].

The fuel and food shortages in German Bohemia, as in Vienna, were bad in 1917. By January 1918, the situation was critical. The fact that the Czech-inhabited Central plain was relatively well off resulted in accusations of hoarding, which only increased tensions.

One week after declaring their parliamentary opposition to Seidler, the United German-Bohemians published their own declaration of "German-Bohemian Staatsrecht." The very use of the sacred Czech motto indicates a real desire to fight back with language equal to that of the Czechs.

The salient points of the Staatsrechtlichen Deklaration der Deutschböhmischen Abgeordneten are as follows:

In these times of troubles the revolutionary Czechs seek to exploit the situation, smash the Empire and place 3.5 million Germans under the yoke of a Bohemian Slav state. [For these reasons the]... people of Deutschböhmen demand the establishment of an autonomous Deutschböhmischen Provinz with all rights and privileges of a Crownland within Imperial Austria and with no ties to the Czech part of Bohemia what-so-ever. [In addition to their] - - right to live free of Czech bondage, [they also declared] ... that we no longer recognize the Provincial Diet of . . Bohemia [at Prague]. [78] 
This represents a marked change in the German attitude toward their role in Bohemia. The Whitsuntide Plan advocated control of the Prague Diet, while now the German wished no connection to it at all. It would appear that the Germans of Bohemia were tacitly recognizing the autonomous position of the czechs so as to have their own position recognized as the same. They also demanded the formation of German Kreise within which schools, official language, etc., would be entirely controlled by the Germans.

The borders of these individual German Kreise, according to Radical German Party leader Dr. Raphael Pacher, chief draftsman of the declaration, already existed along the constituency borders drawn for the Reichsrat elections of 1907 [79].

And so by February 1918, both Bohemians, Czechs and Germans had each presented their claims before the official forum in Vienna, such as it was.

\section{FOREIGN INTERVENTION}

Meanwhile, though the Czechoslovak National Council in Paris was recognized as a belligerant ally, French, British and American administrations were shying away from any commitment of recognition of the proposed borders of the future state. Indeed, the breakup of the Austro-Hungarian Empire was initially rejected as an allied war aim. The 
rights of oppressed peoples was one thing; the destruction of Central European unity was quite another.

In February 1917, the U.S. Secretary of State directed his Ambassador to the Court of St. James to inform the British government of President Wilson's desire to keep Austria-Hungary intact.

The President believes . . that were it possible for him to give the necessary assurances to the government of Austria, which fears radical dismemberment, he could force the acceptance of [a separate] peace. [80]

Great Britain and France were vacillating, however. In Mr. Balfour's address to the Imperial Council on Foreign Policy of May 1917, he stated, "As regards Bohemia . • [which] has a hatred of German civilization . . ," apparently not realizing that two-fifths of Bohemians were Germans," . . whether . . all these feelings could not be satisfied by giving Bohemia some sort of autonomy in the Empire I am not so sure" [87].

It was not until the spring of 1918 and the failure of a separate peace that the U.S. and Entente Powers began recognizing the individual national councils as de facto representatives of future states and that the AustroHungarian Empire must perish.

The joint support extended by the west to the Congress of Oppressed Races of Austria-Hungary held in Rome in April 
1918 reveals that commitment. The American Secretary of State said that the proceedings were followed with great interest " . . and that the nationalistic aspirations of the Czecho-slovaks . . for freedom have the earnest sympathy of this Governemnt" [82].

A few days later Italy, France and Great Britain sent notification of Allied solidarity:

The Allied Governments take note with satisfaction of the declarations by the secretary of state . . and desire to associate themselves with it in expressing . . sympathy for the national aspirations . . of the Czechoslovak . . nation. [83]

Now, sympathies and support were all very fine, but they were not enough.

The aim of the Czech policy was to obtain from the Allies a definite promise that they would establish an independent Czechoslovak state, [but most importantly]... within the frontiers stipulated by Masarýk. [84]

Of course, Benes required that the boundaries " . - not be drawn according to the principles of nationality" [85]. Such action would leave the future state with no more territory than the Bohemian Germans were willing to concede. Such requirements were met on June 23, 1918, when French Foreign Minister Stéphen Pichon handed Benes a note which stated that France would 
- . recognize . . officially the National council as the supreme organ . . . of the Czechoslovak Government. The historic rights of a nation cannot be destroyed . . . and at the proper time [the Government of the Republic of France] will endeavor . . . to secure your aspirations to independence within the historical boundaries of your provinces. [86]

Prime Minister Lloyd-George and President Wilson were unwilling to commit themselves to any territorial promises to the Czechoslovak National Council, stating instead that territorial delimitations were to be settled at the Peace Conference--the invitation to which was extended to the Czechoslovak National Council.

Missives of Secretary of State Lansing to President Wilson clearly show the legal and official posture the Americans wished to assume--a position Beneš would eventually play against that of France.

I do not think it wise to give full recognition to the Czecho-slovaks as a sovereign nation. . . . I think [a] declaration would have to contain a reservation as to territorial limits. [87]

Wilson heeded Lansing's advice and worked out a plan to recognize the Council based on its Allied war efforts only and not on Czechoslovak territorial claims.

The President then sent to Lansing's desk the following draft which was passed to the Czechoslovak National Council: 
The Government of the United States . . recognizes the Czecho-Slovak National Council as a de facto belligerent clothed with proper authority to direct the military and political affairs of [the same]. [88]

Wilson noted on the margin that he felt that Lansing had ". . successfully stated both the actual facts and the new legal relationship which we assume...W.W." [89].

Therefore Benes could procure the territorial blessings only from France. Great Britain and the U.S. held steadfast to the idea of nothing being decided until a peace conference could be convened. Thus, two divergent interpretations emerged of what the map of Europe looked like in mid-1918. Wilson and Lloyd-George recognized the continuation of the Austro-Hungarian Empire until such time as the peace conference dismantled it. Clemenceau, on the other hand, saw her as already in pieces.

\section{COLLAPSE}

While Benes and Masarýk were consolidating the Czech position in the Allied camp during the summer of 1918, the machinery of the Austro-Hungarian government was plodding along--if only by inertia.

In Bohemia, the German Nationalists, if no longer so sure of a Central Power victory, were ever confident that the establishment of their autonomous province was just around the corner--national self-determination having become 
the catch word of victor and vanquished alike based on Wilson's Fourteen Points of January 1918.

This German-Bohemian confidence was evidenced in the press which reported the daily debates of parliament in Vienna.

Five months after the German-Bohemian declaration of their own Staatsrecht, the leading Bohemian newspaper ran this story on the front page:

Informed circles indicate the order for the Einkreisung [formation of homogenous Kreise] imminent. - . Preparations have advanced though not complete, especially concerning the national demarcations of Pilsen and Budweis. [90]

Both Pilsen and Budweis, long controlled by a German municipal adminstration, were among those cities "lost" to the Czechs during the migration of the last years of the previous century. In truth there never was a German majority in either city, and by the 1921 census both showed less than 188 German [91].

The article went on to list the six German Kreise which were to be erected along Bohemia's borders with Prussia, Saxony, Bavaria and Upper and Lower Austria: Eger to the extreme west and stronghold of the most avid nationalists; Reichenberg to the north where the provincial capital of the same name was to be located; Leitmeritz, which encompasses the Erzgebirge rich with lignite deposits and runs along 
northwest Bohemia between Eger and Reichenberg; German Pilsen in the central west; German Budweis in the south, and Trautenau along northeast Bohemia, which encompasses the mineral-rich Sudeten Mountains. (See Appendix, Map 3.)

Czech Bohemia was divided up into nine Kreise, which clustered in the center of the country. Two days later the headlines asked:

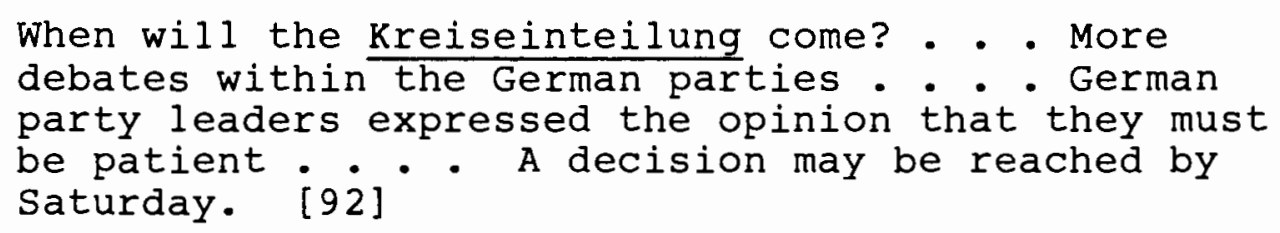

After a brief recess of Parliament the news on May 14 clearly indicated a pattern . . "Postponement of the Kreiseinteilung due to Czech Holiday" [93].

Apparently Dr. Seidler considered it bad form to destroy Czech national aspirations of their historic rights on the three hundredth anniversary of the prague Defenestrations. "The Minister President [Seidler] wants to spare the sensitivities of the Czechs" [94]. Further it was decided " . . that decisions would not be made in the immediate future, . . perhaps after Monday" [95].

Instead of printing the story of the failures of the great German offensives, the May 25 edition of the Prager Tagblatt ran a map showing the dispersal of the now five Kreise. (Pilsen was abandoned, but the surrounding German 
Bezirke were to be attached to the Eger Kreise.

still nothing could be settled. Seidler's efforts to reach a settlement ended with his fall in July. Baron Hussarek, his successor, though Czech, was unloved by the new Vienna-based Czech National Council led by Karel Kramár himself, who three years earlier was awaiting execution for treason.

Hussarek tried to soothe the Germans by vague promises of partition in Bohemia but found that this only infuriated the Czechs while not really appeasing the Germans [96].

During the last months matters had so deteriorated as to render the empire ungovernable. The Piave Front was breaking up, and the Germans were in complete retreat in the West. Wilson's ambiguous reply to Emperor Karl's request for peace prompted the hapless last Habsburg to make his last-ditch effort to hold the Empire in mid-october. "A slapdash constitutional reform granting autonomy to the nations in the Austrian part of the Empire was prepared in a form of an Imperial Manifesto" [97]. Dr. Wiskemann refers to it as a ". . voice from the grave."

Even the most ardent German nationalist now recognized that the various nationalities of the Empire no longer needed an imperial manifesto to set up their respective states. An official communique from the Eger City Council states: 
Now it has gone so far that the establishment of a Czech state seems to be indeed the case. It is for that reason that our . . . just claims for the establishment of an autonomous province of GermanBohemia be fulfilled. German Bohemia and Egerland will never subject themselves to the Czechs. [98]

The situation was indeed fluid, and events were occurring at break-neck speed.

On October 29 , the Bohemian citizens read that on the day before, the Imperial Viceroy or staathalter in Prague, count Coudenhove, " . . had taken an extended vacation" [99]. That same day, four Czech representatives of the Vienna branch of the Czechoslovak National Council, Rašin, Švehla, Soukup and Stribrný quietly looked over the government in Prague in a " . . businesslike rather than heroic fashion" [100]. 
1. Susan G. Konirch, "Constitutional Aspects of the Struggle Between Germans and Czechs in the AustroHungarian Monarchy," Journal of Modern History 27 (1955, p. 235.

2. Ustredni Matice Skolská was the Czech counterpart to the German Schulverein, also of 1880. The aim of both was the assurance of an education for their respective children in the language of their birth. They tended to be very nationalistic in nature. Indeed, the Schulverein membership was largely represented by the German National Socialists--precursors to the Nazis and strongest in Bohemia. The Czech Matice self-confessed aim was the "retaking" of Bohemia--school by school.

3. Wiskemann, p. 39 .

4. Seton-Watson, Czechs and Germans, p. 228.

5. Kann, History of the Habsburg Empire 1526-1919, p. 439 .

6. Ibid., pp. 439-40.

7. Ibid.

8. Campbel1, Confrontation in Central Europe, p. 20.

9. Klemens von Klemperer. Igraz Seipel: Christian Statesman in a Time of Crisis (Princeton: Princeton University Press, 1972), p. 23.

10. Andrew Gladding Whiteside, Austrian National Socialism Before 1918 (The Hague: Martinus Nijhoff, 1962), p. 30 .

11. Marx and Engels originally believed that the proletariat revolution would follow on the heels of the bourgeois revolution. "Inasmuch as the bourgeoisie revolution had already taken place in France [in 1789], they thought that Germany would be next in line." See James Edward LeRossignol, From Marx to Stalin (New York: Tomas Y. Creswell Company, 1940), p. 55. See also Marx and Engels Communist Manifesto (New York: Pathfinder Press, 1983), p. 44.". . the Communists 
turn their attention to Germany, because that country is on the eve of a bourgeois revolution [and will be]. - the prelude to an immediately following proletariat revolution." After the failure of 1848-9 Marx admitted that they had been premature but still believed that Germany, albeit later than hoped, would be the center of the central European revolution. They also later condemned the Social Democrats' 'bourgeois tendencies' as impediments to that revolution; the importance of the Germans remained.

12. Whiteside, Austrian National Socialism, p. 15.

13. Campbell, p. 21.

14. Whiteside, Ibid.

15. William Wallace, Czechoslovakia (Boulder: Westview Press, 1979), p. 43 .

16. Seton-Watson, Czechs and Slovaks, p. 226.

17. Ibid., p. 227.

18. Ibid.

19. Ibid., p. 229 .

20. Ibid.

21. Ibid., p. 232 .

22. Wiskemann, p. 44 .

23. In 1871 a new set of 18 Fundamental Laws was signed by the Emperor which more closely defined Article XIX of the 1867 constitution. See Berthold Sutter, Die Badenischen Sprachenverordnungen von 1897 I. Band (Graz: Verlag Hermann Boehlas Nachf., 1960), p. 291.

24. Sutter, Badenischen Sprachenverordnungen 1897, Art. II, S. I., p. 277 .

25. Seton-Watson, Czechs and Slovaks, p. 237.

26. Ibid. 
27. Hans Mommsen, Die Sozial Democratie und die Nationalitätenfrage im Habsburgischen vielvolkerstaat: Das Ringen um die Supranationale Integration der Zisleithanischen Arbeitbewegung 1867-1907 (Vienna: Europa-Verlag, 1963), p. 314 .

28. Kann, Vol. II, p. 154 .

29. Ibid., p. 155. Schönerer nationalists and the PanGerman party also urged the maintenance of German leadership emanating, however, from Berlin, not Vienna.

30. Ibid.

31. Mommson, Die Sozialdemokratie, p. 314.

32. Kann, Vol. II, p. 155.

33. Hugo Hantsch, Geschichte Osterreichs 1648-1918, Vol. II (Graz: Verlag-styria, 1968), p. 450.

34. C. A. Macartney, National States and National Minorities (New York: Russell and Russell, 1968), p. 149 .

35. Sutter, Vol. II, p. 462 .

36. Ibid., p. 465 .

37. Ibid., pp. 466-7.

38. Wiskemann, p. 54. (See also David Lloyd-George, Memoirs of the Peace Conference, Vol. II [New York: Howard Ferlig, 1972], pp. 606-7).

39. Sutter, Vol. II, p. 466.

40. Paul Molisch, Die sudetendeutsche Freiheitsbewegung in den Jahren 1918-1919 (Wien: UniversilatsVerlagsbuchhandlung, 1932), pp. 6-7.

41. Br. Mitchell, European Historical Statistics 1750-1975 (New York: Facts on File, 1981), p. 86.

42. Wiskemann, p. 68 .

43. Kann, Vol. I, p. 205.

44. Seton-Watson, Czechs and Slovaks, p. 238. 
45. Sutter, p. 461.

46. Kann, Vol. I, p. 207.

47. Wiskemann, p. 52 .

48. Kann, Ibid.

49. Hantsch, p. 464.

50. Ibid., p. 466 .

51. Seton-Watson, Czechs and Slovaks, pp. 244-5.

52. Ibid., p. 229 .

53. Molisch, p. 8 .

54. Eduard Benes, Le Problem autrichien et la Question Tchèque, quoted from Molisch, p. 9 .

55. Benes, quoted from Kann, Vol. I, p. 212; Kann's parentheses.

56. Kann, Vol. I, p. 210.

57. Ibid., p. 211

58. Molisch, p. 9.

59. Ibid, p. 10 .

60. Wiskemann, p. 76 .

61. Thomas Garrigue Masarýk, The Making of a State: Memoirs and Observations 1914-1918 (New York: Prepared by Wickham Steed, Frederick A Stokes Co., 1927), p. 26.

62. Seton-Watson, Masarýk in England (Cambridge: University Press, 1943), p. 128.

63. Seton-Watson, Czechs and Slovaks, pp. 285-6.

64. Hantsch, p. 516 .

65. Friedrich Naumann, Central Europe (New York: Alfred A. Knopf, 1917), p. 10 $\overline{8}$, my parentheses.

66. Molisch, p. 11. 
67. Kann, Vol. II, P. 242 .

68. Harold W. V. Temperley, A History of the Peace Conference of Paris, Vol. IV /London: Henry Frowde and Hodder \& Staughton, 1921), pp. 250-1.

69. Wiskemann, p. 76.

70. Temperley, Vol. IV, p. 255.

71. U.S. Ambassador (Sharp) to Secretary of state (Lansing). Translation of french note in response to War Aims. January 10, 1917. Papers Relating to the Foreign Relations of the United States, 1917, Supp. I. (Washington: Government Printing Office, 1931), p. 8 . (Hereafter referred to as FRUS.)

72. Temperly, Ibid.

73. Ibid.

74. Seton-Watson, Czechs and Slovaks, p. 294.

75. Prager Tagblatt (Prague Bohemian Crownland of the Austro-Hungarian Empire), January 16, 1918.

76. Ibid.

77. Ibid.

78. Address of Deputy Dr. Rafael Pacher in Lower House of the Austrian Parliament, January 21, 1918. Prager Tagblatt, January 22, 1918 .

79. Ibid.

80. Robert Lansing to W. H. Page, February 9, 1917. FRUS 1917, Supp. I, W. W. P. 40 .

81. FRUS, Lansing Papers, Vol. II, p. 25.

82. Lansing to Page, May 29, 1918. FRUS, 1918, Supp. I, W.W. I, P. 809 .

83. Declarations of the Allies for the Oppressed Nations, June 3, 1918. Quoted from D. Perman, Shaping of the Czechoslovak state, p. 33 . 
84. D. Perman, The Shaping of the Czechoslovak State:

Diplomatic History of the Boundaries of Czechoslavakia, 1914-1918 (Leiden: F. J. Brill, 1962), p. 33.

85. Ibid.

86. Pichon to Benes. Quoted from Perman, p. 37.

87. Lansing to Wilson, August 19, 1918. FRUS Lansing Paper, Vol. II, pp. 139-41.

88. Wilson to Lansing, September 2, 1919. FRUS Lansing Papers, Vol. II, pp. 144-5.

89. Ibid., p. 145 .

90. Prager Tagblatt, May 4, 1918 .

91. Wiskemann, pp. 108-9.

92. Prager Tagblatt, May 6, 1918.

93. Ibid., May 14, 1918.

94. Ibid.

95. Ibid.

96. Seton-Watson, Czechs and Slovaks, p. 304.

97. Perman, p. 49 .

98. Official communique from the Eger City Council, October 17, 1918. Printed in the Prager Tagblatt, October 18, 1918.

99. Prager Tagblatt, October 29, 1918.

100. Wiskemann, p. 80 . 
THE ESTABLISHMENT OF THE GERMAN-BOHEMIAN PROVINCIAL GOVERNMENT

On the morning of October 29, 1918 the German-Bohemian national leaders, who ten days earlier had sworn never to subject themselves to a Czech state, woke up citizens of Czechos lovakia.

There was no time to lose.

In answer to the Czech action on October 29, the delegates from Bohemia met in Vienna and proclaimed the establishment of the Autonomous Province of German Bohemia, stating that it was to be a part of the new German-Austrian State in accordance with Wilsonian principles of the right of national self-determination.

The next day the Austrian National Provisional Assembly, made up of those members of the Reichsrat who represented German-Austria, accepted the German-Bohemian Province as part of the new Austrian State [1].

Thus, the German areas of Bohemia were both recognized by and represented in the de facto government of Austria.

The tenets of the German Bohemian position, as they appeared in the Proclamation of October 29th 1918 were fundamentally based on denials of Czech claims to the German 
territories of Bohemia. They can be summarized into three major areas. "The Czechs claim German Bohemia belongs, historically, to their state but yellowing parchment cannot abolish the living rights of the German people" [2].

The Germans pointed out what they saw as glaring inconsistencies and double standards in the Czech Staatsrecht historical claims.

The Czechs, who, on the basis of the nationality principle claim Hungarian Slovakia, although it has historically never been part of their state, have no right to deny the German people that same nationality principle [in their desire to remain Austrian]. The Czechs further claim that to retain German-Bohemia [the Germans preferred the word 'annex'] . . . would have . . . economic and strategic advantages . . to their state... , but no people have the right to violate another race to insure their own economic [prosperity] or to insure their borders strategically. [3]

The economic issue was indeed important for a mutual dependency existed between the Czechs and Germans in Bohemia. It was a double-edged sword for the Germans of Bohemia: the gain of their territory meant the loss of their principal foodstuff source, a source guaranteed them only by inclusion into the Republic of Czechoslovakia. At the same time, though inclusion meant food for the Germans in Bohemia, it meant to Austria proper the loss of her principal industrial areas. Bohemian coal was essential to the life of Vienna as well as Graz, Linz and Salzburg. The loss of German-Bohemia would make an Anschluss with 
the German Reich all the more necessary if Austria were to survive as a state. One can be sure that the motives of Vienna to keep German-Bohemia were based more on the hard facts of economics than were those of the more romantic nationalists in Reichenberg, the new provincial capital. The third principle of the German rejection of Czech claims came in the form of a prophetic warning: "If the Czechs carry through with their 'annexation' plans, it will only do them harm. Czechoslovakia would then contain a [strong] German irredenta" [4]. One would presume that referred to a desire to again be Austrian, but it must be remembered that most Germans believed that, in accordance with the wilsonian principles of national selfdetermination, an Austro-German Anschluss was imminent.

- . frightened by the prospect of Slav domination and worried about lack of food and fuel, GermanAustrians from all classes and political parties abandoned the Habsburg throne and sought refuge in a national destiny with their fellow Germans. [5]

Also important is Article II of the Proclamation which allows the Governor of Deutschbohmen control over finance, justice and the right to raise a Volkswehr or militia.

The almost comical twist to the brazen declarations of both sides is that neither Czech nor Bohemian-German as of yet had any military might with which to enforce their demands. The Armistice would not begin for another week and 
even then most returning soldiers, especially German, were little inclined to put their uniforms back on. The czechs did have some limited resources in their re-enacted sokol units, and within a few weeks they would have an army; but for the time being both lacked any real means of enforcing their proclamations.

Within days the German delegates from Moravian and Silesian German areas joined the Bohemians and declared themselves part of the Austrian Republic. And so by November 1, all three Crownlands of the former Kingdom of Bohemia had delegates sitting in the German-Austrian Provisional Government in Vienna.

The German-Bohemian Province was easy to establish. The basic outlines had been worked out on paper for nearly twenty years.

The borders of the German Kreise were drawn according to the electoral Bezirke of the 1907 parliamentary election $[6]$.

In the south a fairly homogeneous strip, the Bohemian Forest District, lay along the frontier of Upper Austria, and local leaders in Krumau hoped to eventually attach their area to the administration in Linz [7].

In the north and west of Bohemia (which bordered Prussia, Saxony and Bavaria, not Austria) lived the largest concentration of Germans. The nationalist stronghold of 
Reichenberg was the obvious choice for its capital and was soon considered the capital of all German-Bohemia [8], with Radical Party Deputy, Dr. Raphael Pacher, as its governor.

Moravia and Silesia, having a different history in regards national demarcation, were a bit more complicated. Southern Moravia, like southern Bohemia, had an indisputable strip of German territory which ran along Austria's northern border. The German-Moravian leaders in the southern Moravian city of Znaim hoped to incorporate it eventually into lower Austria [9].

In Austrian-Silesia the German Nationalist Party Deputy Dr. Freissler became governor and set up his government in Trappau; he claimed responsibility for the Germans of Silesia, North Moravia and parts of East Bohemia; and, after rejecting the proposed name of Altvaterland, gave this combined area the name of Sudetenland, which later became the general term for all German areas in Czechoslovakia [10].

In Moravia there existed several Deutche Sprachinseln-Brunn, olmütz, Zwitlau, and others--and so a fifth national council was set up for Brunn and central Moravia. (See Appendix, Map 4.)

The fact that the greatest number of Germans living in the Crownlands did not border the German-Austrian state was not of great concern. The day after Emperor Karl's 
abdication on November 11, 1918, the Austrian Democratic Republic proclaimed itself part of the German Republic.

At the time, the individual provisional governments set up in Reichenberg, Troppau, Krumau and Zniam seemed the best transitional arrangement until the awaited Anschluss could be completed [11]. Those areas not attached to Austria proper would then simply become parts of Bavaria, Saxony and Prussia later.

In early November Dr. Pacher was offered the post of Minister of Education in the new Austrian Socialist Government of Karl Renner, and he took it. Dr. Rudolph Lodgmann, Progesssive German Party leader, took over the governorship from Pacher and chose the able Social Democrat Joseph seliger as his deputy governor.

It must be remembered that the Germans of the most radical nationalist variety did not advocate Zweiteilung, but total domination of Bohemia such as suggested in the Linz Plan and the Easter Demands of 1916. Thus, the leaders of the German-Bohemian Provisional Government were not of that type and should never be compared with Henlein or the Nazis of seventeen years later. George Schönerer and Hermann Wolf were indeed Bohemians from Egerland, but they were not part of the then-German leadership.

The new democratic government of Renner and Adler had no problem with the establishment of the Czechoslovak 
Republic; they actually sent congratulatory greetings to Prague. It was only the territorial delimitations that were at issue [12]. The Renner government therefore recognized the government at Prague and hoped to open doors for discussions by sending Lodgmann to Prague to discuss food and coal shipments as early as october 30,1918 . It seems the Czechs had halted shipments of what they now considered their coal from German North-Bohemia to Vienna--a city highly dependent on the food and resources the vast empire had previously supplied [13].

Lodgmann was instructed to skirt the territorial issue and discuss aid only, but the Czechs would have no part of it. Discussions precluded recognition of authority in the German areas and so, with neither accepting the credentials of the other, the talks could not even begin. On November 4 Seliger himself tried his hand but was rebuffed with the famous remark, " . - with rebels we do not negotiate," first used in 1848 by Prince windischgraetz to the Czechs during the Prague uprising.

Besides the terrible lack of food and fuel and probably because of it, Lodgmann was faced with another problem. There was, beginning in November, an increase in social unrest that had a Bolshevik hue to it. Reports from the workers' districts of German cities in North-Bohemia were increasing. The November $34 \mathrm{~d}$ Prager Tagblatt reported, 
The city [Aussig, Lodgmann's own constituency] and environs today looked like a scene from the Russian Revolution. . . The rice grainery was burned and millions worth of food and clothing have been plundered, . . machine gun fire could be heard - . six persons die. [14]

There was nothing unique about the troubles in Aussig. On November 4 the press reported that in Innsbruck and Linz

- . crowds formed demanding their october

al lotments of sugar from the Neftomitzer Refinery - . and were under the leadership of soldiers. City militia with machine guns have taken up positions. [15]

The fighting ended in the trenches and was resumed in the streets as the soldiers began coming home. Many returning soldiers were of a definite leftist bent. The horror of the trenches produced few monarchists and made Socialists out of many nationalist bourgeoisie of pre-War days. This new communist inclination had many leaders worried, Lodgmann among them.

\section{OCCUPATION}

As mentioned above, the German-Bohemian government had precious little at its disposal with which to squelch social unrest. Help would have to come from elsewhere. Governor Lodgmann had two choices: appeal to the German Reich for troops across Bohemia's northern and western borders (Aussig lies only 30 miles from the Saxon border, 130 miles from 
Austria), or request military aid from the now-growing Czechoslovak Army.

The latter would be forthcoming if summoned, but Lodgmann correctly feared, as he states in a letter to Pacher,

- - solicitation of Czech military aid to squelch unrest would, in effect, dislodge the German [government in Bohemia] and recognition of [the] Czech Army and nation would follow. [16]

The former had little hope for success for, as early as mid-October, the idea of a German Reich military intervention in German-Bohemia had been rejected by wilhelm II himself. Only the representatives of the German General Staff were in favor of such action. The representatives of the Saxon Legation in Vienna observed dryly, " . . the gentlemen of the military are always willing to march off somewhere" [17]. As it turned out, however, cooler heads prevailed. The Saxon Legate in Vienna advised his capital in late October:

- . such action las suggested by the aforementioned General Staff] would disrupt the peace negotiations [then underway]... and poison our [Saxony's] advantagous relationship with our Czech neighbor. [18]

In the end it was to the Czech authorities that the plea went. And, as Lodgmann had feared, the Czechs did not come to squelch unrest but to occupy. 
On November 10, the Saxon Attachë, Bendorff, attached to the Saxon Legation in Vienna, sent Dresden reports that

- . the Czechoslovak military has been moving into both partially and wholly German settled areas [of Bohemia] . . and [units] are moving into the Sudetenland of [North Moravia and Silesia]. [19]

The Czechs, starting from Aussig, slowly and meeting virtually no resistance, began occupying German Bohemia. Again Vienna and Reichenberg appealed to Saxony for assistance, this time, however, not to restore order but to help the German-Bohemians push back the Czechoslovak "invaders."

Bendorff to Dresden:

They [Austrian Provisional National Assembly] have requested of me to convey the request of immediate arms and munitions. Czech border officials [are] disarming returning German-Bohemian troops at the borders . . very little ordinance on hand . . Saxon attack desired only as last resort. [20]

On the eve of the Armistice of November 11 in Germany and a full week after that of Austria-Hungary, the Vienna representative of the German General Staff, General von Crabon, designated which arms would be required to repel the Czechoslovak army of the Allied Powers: " . . twelve artillery pices, 12,000 shells, 3000 rifles with 1.5 million rounds, 30 machine guns with 300,000 rounds..." [21]. Germany at this time, besides having her own domestic 
clashes, was attempting to put on her best face for the upcoming peace conference. Aiding in military action against a recognized government of the Entente, which Czechoslovakia now was, was hardly consistent with this attitude.

Dresden and Berlin spoke volumes by their refusal to even reply to Vienna's requests.

\section{DIPLOMATIC CAMPAIGNS}

Throughout mid-November Czech troops returning from Italy and France, Sokols and returning Czech Legionniers, and a newly-organized home army, of which more shall be said, were moving into the isolated mid-Moravian German "language islands."

Lodgmann then appealed to President wilson through the neutral Swedish Embassy on November 13.

In the name of 2.5 million Germans in Bohemia who, appealing to the right of self-determination, consider themselves $a$. . . part of the free German Austrian Republic [proclaimed the day before] - . . We protest against the armed forces of the Czech state. It is plain that the Czechs want the German population to relinquish its right to selfdetermination and to forestall a free agreement -. at the Peace Conference. [22]

The German-Austrian government sent notes to Washington in support of Lodgmann, one of which came in the form of a proposed solution. After reiterating the argument extolling 
the true German character of the territory under question, the new Foreign Minister, Dr. Otto Bauer, challenged the Allies, "If the Allied Powers have no doubt . . , " in terms of the German-Bohemian loyalty to the German-Austrian Republic:

- . the - . Government proposes, - . without delay, . . a plebiscite . . guided by neutral authorities. The Austro-German Government asks the Allied Powers not to decide upon the fate of the people in question except upon the basis of this plebiscite. [23]

What Bauer was requesting is that decisions not be made on the basis of the Czechoslovak faits accomplis, i.e., occupation. Benes, meanwhile, was attempting that very thing, namely to secure diplomatic territorial recognition based on occupation, which, by December, was all but complete.

To understand the position the Entente took in response to the requests of Lodgmann and Bauer, one must first understand the relationship between Benes and the Entente. Benes, in order to secure both the means and the sanction of occupation, needed to convince his Allies of the value of a strong Czech military position in Central Europe. This he did first by understanding their goal--the defeat of Germany; and secondly their fear--communist agitation in East-Central Europe.

As early as October 1918, the Czech leaders were 
working on the establishment of a Czech army within the homeland. When in late october the plan was put forward for an Allied offensive from the southeast, Austria-Hungary was seen as the ideal springboard for such an attack. The plans of October 31 called for

- - free movement over road and rail in AustroHungarian territory. Armies shall occupy such strategic points as they deem necessary... to conduct military operations or maintain order. [24]

This was Bene' ' chance. What better way to get a military force into Bohemia than to offer one's services for the movement through territory about which French, British and American commands knew so little and the czech units fighting in Italy and France knew so much? With Czech forces " . . occupying such strategic points as they deem necessary . . " the Czechoslovak National Council would be in complete military and territorial control of the Crownlands and Slovakia by mid-November, or so Benes thought.

Unfortunately for Benes, Germany was unwilling to cooperate with his scheme and surprisingly signed the Armistice on November 11. In one fell swoop there was no longer a need for an Allied presence in the crumbling empire.

Thus Benes could not get an army into Czechoslovakia on 
the Allied Powers' coat tails, but he did have one great advantage. The nullification of the offensive plan left no plan at all. Neither power had, in November 1918, any articulated plan for the defunct empire--Benes would fill that vacuum [25].

By November 9, Benes had notified Kramár, now in Prague, that a French military mission to Prague would organize a Czechoslovak army, not composed of Allied troops, but of Czech troops.

- . by military convention between Czechoslovakia and France. . Czech forces technically became Allied troops and . . could participate in carrying out the terms of the Armistice. . . which included the right to 'occupy strategic points' within Austro-Hungarian territory such as the Bohemian borderlands of the west. [26]

What is more, the Czechoslovak Army was placed under the command of Marshal Foch, Supreme Allied Commander-mo one could question its authority.

How did Benes pull it off?

Unable to get into Czechoslovakia once the offensive was cancelled, Benes then convinced the Allies that a Czechoslovak military presence in Central Europe was the only thing between order and anarchy--between democracy and communism.

The Czechoslovak Foreign Minister, still operating out of Paris, sent his own diplomatic communiquë to London, 
Washington and Paris to counter Bauer's proposed plebiscite idea. Benes painted a picture of utter chaos in Austria and blamed it on Bauer.

\begin{abstract}
The German population of Bohemia . . is quietly accepting its incorporation with the Czecho-slovak state. It is only Vienna by agitating Bohemia that wishes to discredit us (to the Entente). . . (The Vienna Government threatens the Entente with Bolshevik revolution in Vienna) and [blames] the Czechs because [we]. . . refuse to supply Vienna with food and coal. [27]
\end{abstract}

Vienna was indeed starving and freezing in winter 191819. According to American Relief Administration personnel in a missive dated 16 December, "We [have] a most acute situation in Vienna which city has less than ten day's supply of food." And in early January, "We [are] only days away from starvation in Vienna. The Communists are conspiring to take over" [28].

Benes goes on to say in his missive to Lansing:

- . it should be noted that Vienna continues to send arms across Bavaria and Saxony to equip [the Bohemians]. Mr Bauer . . . is a minority Socialist who participated in the Bolshevik revolution in Petrograd in 1917. [29]

Dr. Beneక did not disclose his sources of information on arm shipments.

To cure the "communist plague" in central Europe, Benes suggested that 
Prague be permitted to establish order within its territories of the Historic Borders [and that] - . a temporary decision [be made] to be later examined, . . but, for the present the German inhabitants and adjacent [Austrian] Government would have to submit to the arrangement. [30]

Benes entreated his most agreeable ally, France, to obtain a joint declaration of approval for the provisionary acceptance of the occupation as a territorial delimitation. Knowing the resolve, especially of Washington, in remaining aloof until a conference could be convened, France attempted to obtain no joint declaration, but instead acted independently, as it already had in Czechoslovak matters, and approved Benes' request of provisional territorial recognition, thus, in effect, presenting the United States and Great Britain with a diplomatic fait accompli [31].

The British were genuinely concerned about the vast German populations in Bohemia and thought about perhaps attaching some indisputable German-Bohemian salients, such as Rumfort, Eger and even Reichenberg, Lodgmann's capital, to the German Reich [32].

But, in the interest of Allied cooperation, France convinced Great Britain to communicate with Vienna, though Lloyd-George took a slightly different tack. He informed Bauer that a plebiscite could not be conducted, as all territorial matters must wait for the Peace Conference. 
[We] are of the opinion that pending the decision - . the frontier of the Czechoslovak Republic should coincide with the historical boundaries of the provinces of Bohemia, Moravia and Austrian Silesia. [33]

This, of course, though couched in somewhat more provisional and noncomittal language, is, in essence, exactly what the Czechs wanted. The next day Italy joined England; Benes had three out of four.

The Americans were the most unbending and rejected any discussion at all until the conference.

It was not that Washington was unconcerned or even ignorant, as Clemenceau supposed her to be. Indeed the Americans were so concerned primarily about their ignorance of the "terra incognite" of East Central Europe that they commissioned the "Inquiry," a group of 150 "experts" headed by one Dr. Mezes, to investigate and gather information which would be pertinent to the Peace Conference. The Inquiry had spent more than a year collecting information, much of which Masarýk feared could ultimately lead the Americans to grant German-Bohemia self-determination.

Pending the evaluations of the Inquiry on which the whole American position hinged, neither wilson nor his representative in Paris, Colonel House, would grant the German-Bohemians the right to a pre-Conference plebiscite. Nor would they recognize the Czech occupation of GermanBohemia as a de facto territorial determination. The 
American policy of waiting it out had, by mid-December, become a policy that could no longer be followed, however.

Colonel House in Paris was becoming ever more apprehensive about the threat of Bolshevism in central Europe--especially in Vienna. When he tried to get coal supplies to the Austrian capital he got a quick lesson in geography. House, therefore, had no choice but to entreat Masarýk, now also in Paris, to supply vienna with what the Czechs considered their Bohemian coal.

I [House] had Frazier take Hoover... to see President Masarýk, and authorized him to say that the United States would condemn . . prevention of coal going into Austria for the relief of the suffering population. [34]

Masarýk's reply to Hoover is predictable: "[He] claimed that the coal mines were in possession of the [Bohemian] Germans . . it was impossible for him to take action . . " [35].

Masarýk and Benes saw the chink in the American policy. Benes, in his note to Lansing of November 20 , had already claimed that in order to insure production in the German coal areas, the Czechoslovak territorial jurisdiction must be spelled out. Because " . . lawless bands," which Beneš claimed Bauer supported with arms, have "prevented the mining of coal and its transportation to Vienna" [36]. Although Beneł had addressed his plea for territorial 
recognition to Lansing, it was Colonel House and his staff-Walter Lippmann of the "Inquiry," Stephen Bonsal and others--who would carry on the negotiations.

once negotiations for coal to Vienna started, Colonel House and his staff were caught in the dilemma resulting from, on the one hand, granting power to a recognized government and on the other hand postponing any decision concerning the territorial limits of that government's power [37].

According to Beneš (and only Beneš), the United States government then gave an oral, unofficial consent to Czech occupation. No record shows that any such consent was ever given [38] •

Coal was not received in Vienna for another month. Meanwhile during November and December 1918, one town after another was "falling" to the "Allied" army. On November 16, Prague severed communications between the German-Bohemian capital and her Austrian parent. " . . Telegrams and letters between the Austrian Parliament and Reichenberg have been intercepted and banned by Czech postal officials.." [39].

Between December 7 and 11 Teplitz, Pribram, Marienbad and Aussig (Aussig for the second time) quietly delivered themselves to the Czech army. Teplitz, only days earlier, had been considered for the future capital of German-Bohemia 
due to its more central location than Reichenberg.

On December 12, 1918, with rumors of czech movement toward Reichenberg, the German-Bohemian provisional government and Zweiteilung effectively came to an end.

The Provisional Government [of Deutschboehmen] around seven o'clock this morning, climbed into trucks and fled to foreign soil... The rooms of the government at the Hotel 'Goldener Loewe' have been searched but as yet the Czechoslovak troops have not entered the city . . a late hour telegram places [Governor] Dr. Lodgmann [and company] in Freidland .. . [on the Bohemian Saxon border]. [40]

Ironically, the Czech troops did not actually enter Reichenberg until several days later to a generally indifferent reception. But Lodgman, Seliger and others were now gone, never to return.

By December 14 the erstwhile German-Bohemian leaders had established a government in exile from Vienna issuing proclamations and diplomatic protests as Deutschboehmen herself melted away.

Dr. Freissler, Governor of the Sudetenland, held on until February 1919 and made some honest efforts to procure autonomy within the Czechoslovak state. The government of Znaim held on longest, until March, but only because it was challenged last.

Tomas Masarȳk made his presidential inaugural speech on December 22, 1918. He and Eduard Beneš had their faits 
accomplis to offer up at the Conference in Paris three weeks prior to the opening sessions.

\section{LAST HOPES FOR GERMAN BOHEMIA}

By the time the Paris Peace Conference actually got underway, the Czech occupation of German-Bohemia was an accomplished fact. It was recognized by the "Big Four"-albeit to varying degrees--as a basis for settlement. Foreign Minister Dr. Eduard Benes had little more to say than to claim the old borders of the Three Bohemian Crownlands as they existed in 1914 which, for the first time in their history, the Czechs fully controlled.

The attitude of the Big Four during Benes' initial appearance on February 5, 1919 " . . indicated that they took the existence of the Czechoslovak State for granted" [41]. According to the minutes of Benes' address, LloydGeorge actually interrupted him to say that, " . . no arguments to prove the necessity of [the] annexation of Slovakia were needed--all four Statesmen were convinced of it" $[42]$.

This was not the end of it, however. Though Benes, Masarýk and Kramár had supplied their own plan of action where the Allies had none concerning the defunct Habsburg Empire, the fundamental differences between France, Great Britain and America as to the validity of Czechoslovak 
claims required that the final decision of the "Big Four" (which must be unanimous) be based on the findings of the "Commission on Czechoslovak Affairs."

The hope among the German-Bohemian leaders for a favorable decision based on the findings of the "Commission" was complicated, however, by the appointment of French Ambassador Jules Cambon as the chairman. The Commission was from the beginning heavily loaded toward the well-known French position vis-à-vis Czechoslovakia.

At the first meeting of the Commission the French accepted all Benes' claims with no reservations and was able to get blanket approval from Great Britain, Italy and the United States on the issue of the 1914 borders.

There were voices of reservation, however, chiefly from the American experts assigned to the Commission. Though genuinely concerned over the dismissal of the principle of national self-determination in the German-Bohemian case, they also knew that the wholesale convocation of the principle was impractical, given the economic and strategic realities. There also existed the danger of creating a precedent of national demands in, for example, Ireland, India or the Philippines.

Though anything but ill-informed [43], the Americans who were assigned to the Commission on Czechoslovak Affairs were ill-equipped to match the French in diplomacy and 
negotiations. The wilsonian dream of a just settlement based on correct information supplied by "experts" gave the American delegation little to work with against the "politicians" of, especially, the French.

By mid-March the "Commission" advised the inclusion of three million Germans into the Czechoslovak state.

\section{THE PLEBISCITE QUESTION}

Because the plebiscite was never held, the question of exactly where the population's sympaties lay cannot be easily answered.

Ideologically-charged historiographies tend to give their own answers which range from current soviet to Novotnyan; Nazi to Czech Republican.

Neither the elected officials nor party distribution acted as a viable political barometer of the times, for although elected by universal suffrage, the last Austrian general elections were held in 1911. The lapse between then and late 1918 must be measured in more than time alone. The electorate had simply experienced too much for the elected to still claim the people's unquestioned mandate.

In order to divine what was really going on in the GermanBohemian heart and mind one must read between the lines.

General Populations' Relation to Their Government

The question is then to what extent were the people 
Iinked to the aspirations of their leaders in GermanBohemia? Was it a popular movement, or merely the activities of a small group of men whose political Iivelihood depended on assuming the leadership of a proGerman-Bohemian position?

As already mentioned, the Provincial Government's first concern was procurement of food and fuel, its second to squelch unrest. It was in this turbulent medium that the province was founded in Vienna

. . by a purely legislative act . . about which the people [of German Bohemia] knew nothing for an entire week . . . because the Provincial Government neglected to establish a publicity department. [44]

In fact, a close look at the activities of the Reichenberg government display a surprisingly poorly organized and ineffectual body claiming to be the voice of the people.

The general population was in such a state of collapse that the government could expect little enthusiasm for its activities--demands couched in nationalistic slogans that only tended to complicate matters. [45]

An article in a major Reichenberg newspaper is especially telling of the opinions of at least many Germans that predates the Czechoslovak Declaration of State on October $29,1918$. 
The overheated fantasies which the German politicians throw at us are insane! The Czechs yearn for peace just as we do. . . It is not trenches and barricades we must build along the language borders [Sprachengrenze] but to strike a political [as opposed to military] tactic coming from enlightened, trustworthy representatives. [46]

The relations between the German-Bohemian middle class and their government is of interest here. Many viewed the Viennese government of Renner and Bauer--as they did that of Ebert in Berlin--as being too "Red" for their liking and preferred the more moderate bourgeois climate of Czechoslovakia [47].

When questioned in an interview about this, Victor Adler rejected such notions, but with some reservations.

- . the overwhelming majority of the middle class, as do the working class, are against uniting German-Bohemia with the Czech State. If a portion of the middle class view things differently ... they have been [seduced] by promises of food from the Czechs. [48]

This "seduction" may well be true. There were reports that returning German-Bohemian soldiers would attempt to smuggle their weapons into Bohemia, not to join the Volkswehr but to trade them to the czechs for food. In any case, the conservative leanings of the GermanBohemian middle class were only an indication of the much stronger sentiments of the German-Bohemian industrialists in general. 
Industry's Relation to the German-Bohemian Government

On October 2, 1918, Czech Representative Dr. Staněk addressed a turbulent House of Deputies in the Vienna Parliament. He said: ". . We demand a free... Austria - . and the establishment of a Czechoslovak State is the smallest of our demands!!" German-Bohemian Representative Dr. Wichel cried out, "What about the Germans in Bohemia?" Staněk's reply: "Ask the German factory owners!" [49].

The German-Bohemian industralist had much to gain by attaching the German areas to the Czechoslovak State--and much to lose if they did not. Besides the obvious reasons of mutual economic dependency between agriculturally-rich "Czechia" and mineral-rich German-Bohemia, an AustriaGermany Anschluss, if carried through, would pit GermanBohemian industry against that of the German Reich's much greater industrial capacity.

Even without the Anschluss, the Austrian market, good as it might be, would undoubtedly be hindered by Czechoslovak duties on all shipments passing through undisputed Czech lands between industrial German North Bohemia, the Sudetenlands, and German Silesia en route to Austria.

That the industrialists wished to do business with Prague, not Reichenberg, is definite. 
It was not only the industrialists of Northern Bohemia, but also those of Northern Moravia who were [by 1919] at any rate for the Czechoslovak state. [50]

The growing social unrest was also of great concern to the industrialist class. It condemned the practice of the Reichenberg government to attempt negotiations

- . on purely political demands [and suggested] industrial representatives of both sides to negotiate a quick settlement... for, [they warned,]. . . the social unrest had become so acute that.. . if an agreement didn't quickly come from above... a settlement would from below. [51]

Apparently at least some German-Bohemia industrialists and Benes shared the same fears of Bolshevism.

Military Relation to the German-Bohemian Government

The futile attempt of the Provincial Government to raise a Volkswehr, as already shown, sheds light on the government-to-citizen relationship.

In a letter written by a soldier-council leader to exGovernor Raphael Pacher on November 31, 1919, the general misgivings over being drafted for the volkswehr are evident. "We want immediate disarmament and have no more inclination to be soldiers; come what may, we've had our fill" [52].

The militia that did exist was basically a collecting place for those individuals unable to find their way back to a civilian profession [53]. Many of these were carrying 
revolutionary ideas back from the trenches and attached themselves to the "Peoples' Soviets" scattered throughout Austra and German-Bohemia, but were never coordinated into any real action. They eventually evaporated as the czechs moved in.

A written communique from the District National Committee of Tachau, an all-German Kreis, is telling of the feelings of at least a portion of the German-Bohemian people:

Unfortunately a great part of the urban as well as rural citizens have been incensed by returning German soldiers due to worry over food and basic supplies, the lack of action of the German-Bohemian Government, the unrest in German-Bohemia and the thoroughly unfavorable provisions of the ceasefire. Finally, due to the economic ties of our areas to that of the czechs . . . there remains nothing left but to attach on to the Czechoslovak state. Yes, a great part of the people wish it and it would be best for al1. [54]

When questioned on February 5, 1919," . . whether the inhabitants of these [German] districts, if offered the choice, would vote for exclusion from the Czechoslovak State or for inclusion . . " Dr. Benes answered Lloyd-George that they would vote for exclusion [55].

Because this stands on the record and seems to be contrary to Benes' own statement of the Germans "quietly accepting" czech rule as well as the testimony above, the statement warrants explanation. 
Benes, ever vigilant to cast aspersions on the Vienna government, explained that such a decision to not join Czechoslovakia would be the result of Bolshevik propaganda emanating from the Renner-Bauer government. That is to say that the German-Bohemians were being duped by the Austrian Social Government for Austria's own reasons [56]. If this is true, one must remember that Austria's reasons to retain German Bohemia were based on desperate attempts to hold her former industrial possessions--an understandable economic imperative.

Secondly, the social unrest that Benes blamed on Vienna justified the Czechoslovak Army and excused its occupation of all Bohemia.

In all, it is difficult to say exactly which way a plebiscite would have gone. It is equally difficult to determine just what the basis of a plebescite would be. Self-determination meant different things to different people. Some may have feared that the maintenance of a provincial relationship with truncated Austria might only be possible with an Austro-German Anschluss. Others may have wished the direct attachment to the Reich for purely geographical reasons, even though those very regions, which, though not connected, lay alongside the Reich, would have suffered economically. Some favored an autonomous position within Czechoslovakia--a kind of Swiss system. Others even 
envisioned German Bohemia becoming an independent country and a ward of the League of Nations.

It is quite possible that even if a majority wished to be excluded from Czechoslovakia, a general consensus as to where they wished to be included would have been unreachable. For one must also remember that the German areas of the Crownlands had all experienced different cultural and social histories. Industrial North Bohemia, for example, has very little in common with almost feudal South Moravia.

In real and practical terms, a plebiscite, the purpose of which would be to gauge the feelings of the Bohemian Germans, would have been impractical and inaccurate, if not impossible.

The various territorial settlements of Czechoslovakia's neighbors outlined the new "Successor state" along the new universally-recognized "Historical Borders" of the Staatsrecht principle (except for a few all-German salients which went to the weimer Republic and which Prague was happy to see go).

Dr. Rudolph Lodgmann became the leader of the so-called "Negativists," who refused politically to take part in Czechoslovak politics. A large part of the old German political guard, however, had sufficient political sense to realize--much as the "New Czechs" had in the 1880's--that 
one must work within the political structure if one expects a voice in affairs. These "Activists" or "Positivists" eventually fell into mainstream Czechoslovak politics, while others kept the German Nationalist home fires burning-possibly awaiting a messiah. 
CHAPTER IV ENDNOTES

1. Perman, p. 75 .

2. Proclamation of the Establishment of German-Bohemia, read in Austrian National Provisional Assembly October 30, 1918; Prager Tagblatt, October $30,1918$.

3. Ibid.

4. Ibid.

5. Duane P. Myers, "Berlin Versus Vienna: Disagreements About Anschluss in winter of 1918-1919," Central European History 5 (1972), 151 .

6. Prager Tagblatt, Ibid.

7. Ibid.

8. Ibid.

9. Ibid.

10. Ibid.

11. Ibid., p. 83 .

12. See Proclamation of German Bohemia, Prager Tagblatt, October 30,1918 , above.

13. Perman, p. 89.

14. Prager Tagblatt, November 3, 1918 .

15. Ibid. , November 5, 1918.

16. Lodgmann to Pacher early November 1918. Quoted from Alfred Opitz, "Boehmen und die deutschboehmische Frage in der ersten Phase der Herausbildung des tschehiachen National-Staates in Jahre 1918: Nach Berichten der Sachsischen Gesandtschaft in Wien," Bohemia Jahrbuch des Collegium Carolinium 17 (1976), 200 .

17. Ibid. 
18. Ibid.

19. Ibid. Report from Bentdorff to Dresden Nr. 507, November 10,1918 .

20. Ibid.

21. Ibid.

22. Swedish Minister (Ekengren) to Lansing, November 21, 1918. FRUS Papers Relating to the Paris Peace Conference Vol. II, pp. 337-8. (Hereinafter referred to as FRUS, PPC).

23. Ibid. Attached memorandum from Bauer to Wilson.

24. Colonel House to Lansing. FRUS 1918, Supp. I, p. 434.

25. Perman, p. 73 .

26. Ibid., p. 75 .

27. Benes to Lansing, November 20, 1918. FRUS PPC 1919, Vol. II, pp. 279-83.

28. Herbert Hoover, An American Epic: Famine in Forty-Five Nations, Organization Behind the Front 1914-1923, Vo1. II TChicago: Henry Regnery Company, 1960), pp. 268,364 .

29. Benes to Lansing, op. cit.

30. Ibid.

31. Perman, p. 83 .

32. Ibid., p 84 .

33. British government to the Austrian government through the Swiss Legation in London, January 7, 1919. Quoted from Perman, p. 85.

34. Charles Seymour (ed.). The Intimate Papers of Colonel House Vol. IV (Boston: Houghton Mifflin Company, 1928), p. 240. According to Perman, p. 89, the conversation between Hoover and Masarýk was actually much less demanding than what House intonated to the president: "... no service could be so greatly received by our government . . " 
35. Ibid.

36. Benes to Lansing, op. cit.

37. Perman, p. 91.

38. Ibid., (notes 97, 98).

39. Prager Tagblatt, November 16, 1918.

40. Ibid., December 12, 1918.

41. Perman, p. 131. (See also FRUS, PPC 1919, Vol. III, p. $883)$.

42. Ibid. (See Harold Nicholson, Peace Making 1919

(London: Constable \& Co., Ltd., 1933), pp. 27^8) .

43. Francesco Leoncini, Jahrbuch des Collegium Carolinium, Vol. 13 (1972), p. 350 .

44. Ibid., p. 351 .

45. Ibid., p. 352 .

46. Ibid.

47. Wiskemann, p. 86 .

48. Alfred Opitz, op. cit., p. 203.

49. Minutes of Lower House of deputies reported by Prager Tagblatt, October 3, 1918.

50. Wiskemann, p. 86 .

51. From a communique of the Firma Julius Bendix of Qualisch to the Deutschtoehmisch Landesregierung (DBLR) in Reichenberg. Quoted in Leoncini, p. 352.

52. Quoted in Leoncini, p. 255.

53. Ibid.

54. Ibid.

55. Protocol of meeting between Benes and the "Ten," February 5, 1919. FRUS PPC 1919, Vol. III, p. 881.

56. See Beneక to Lansing, FRUS PPC 1919, Vol. II, pp. 279-83. 
CHAPTER V

\section{CONCLUSION}

Beginning in 1526 the once-independent Bohemian Crownlands were ruled from Vienna in an ever-tightening policy of Austro-German hegemony and centralization. With the Enlightenment came the birth of nationalism which affected both the Central European Germans and their desire for a single nation-state and the oppressed nationalities of the Habsburg Empire, especially the Czechs, in their desire for the re-establishment of their own state. In Bohemia, where both Czechs and Germans had lived for centuries, the clash was inevitable and its reasons complex.

By 1848 the republicanism of France, once imported to Central Europe, had distorted into a web of German-Austrian rivalry with the Czechs caught in the middle. Many AustroGermans, and especially those in Bohemia, desired a great United Germany with Austria participating in a Frankfurtcentered federal republic. The czechs, in seeing such a unity as the destruction of their hopes for the redemption of the Czech State, allied themselves with the Austrian Crown against the German Liberals in an attempt to preserve the Habsburg Empire and their own national survival.

In Bohemia the delicate national balancing act was 
further complicated by the social upheavals of the industrial revolution, which caused vast numbers of czechs to migrate from their central agricultural districts into the mountainous German industrial centers in order to find work.

To the migrating czech it meant simple economic survival; to the czech nationalist leaders the migration represented the "taking back" of the czech Crownlands from the "invading" German settlers. To the German worker it meant competition for jobs; to the German nationalist leaders the Czech migration represented a Slavic invasion of the superior German culture and character of the all-German Bohemian districts.

Attempts to politically isolate the czechs through an elaborate curial system of artifically creating a German electoral majority eventually failed as the Czechs began using the system to their own advantage due to a marked amelioration of the Czech socio-economic position during the latter third of the nineteenth century.

Finally, after a flurry of pro-czech legislation, the German-Bohemians sought to establish the administrative ethnic partition of Bohemia as the only way to preserve the racial integrity of all their German districts. The Czech counter-position to this German $\underline{\text { zweiteilung was staatsrecht, }}$ that is the principle that the crownland's borders were 
externally inviolable and internally indivisible and that the Germans must accept the fact that all Bohemians, Czech and German, have free access within the so-called "Historic Borders."

German proposals were rebuffed by the Czechs. The intransigence of both sides led to wholesale obstructionism in each successive weak coalition government from 1871 to the Empire's demise in 1918.

During the First World War, Tomas Masarýk and Eduard Benes in exile worked with the Entente in an effort to establish an independent Czechoslovakia--something even the most ardent Czech nationalist at home had never proposed. Indeed, the Czechs had always maintained the necessity of a strong empire--albeit a federalized one.

With the collapse of the Austro-Hungarian Empire, both Zweiteilung and staatsrecht paradoxically existed within Bohemia, with the Czechoslovak government in Reichenberg claiming allegiance to the new Republic of Austria.

The German-Bohemians (and Vienna) desperately embraced the principles of self-determination. The Czechs, however, by establishing a fait accompli by military occupation, by correctly pointing out the overwhelming economic and strategic necessity in keeping Bohemia whole, and by masterful manipulation of Allied fears of Bolshevism, French revanchement and everyone's desire for a speedy settlement, 
were able to outstrip the highly principled but inapplicable ideologies of Wilson and establish the Republic of Czechoslovakia with three million Germans within its borders.

The short-lived German-Bohemian government was never really a viable entity, but a reflection of the truly desperate situation the new Austrian government faced once the disintegration of the empire had denied food and fuel so necessary for survival. As for the German people in Bohemia, evidence would indicate that all industry and most of the German middle class wished incorporation into Czechoslovakia.

A plebiscite, as was proposed by Vienna, would have been difficult to administer due chiefly to the unsettled international situation. For one thing, much would have depended on whether an Austro-German Anschluss would have been permitted.

Despite criticism that all would have been different had three million Germans not been included in Czechoslovakia, the gentlemen in Paris, lacking any oracle to divine the future, made the only right choice. Did the Bohemian-Germans then have a legitimate right to the territorial demarcation in pre-War Bohemia? Based on generally accepted notions of the rights of cultural and economic preservation, the answer must certainly be yes. 
To the Germans of Bohemia, their "home" was being invaded, and their home was simply that soil which they and their ancestors had occupied for centuries. They were not Germans from Germany, but Bohemians from Bohemia. What is more, the Germans who had settled in the mountains centuries earlier had not displaced Czechs as the Czechs were most certainly doing in their own economically-induced migration west into the German areas during the nineteenth century. Did, then, the Czechs have a legitimate right to migrate into the German areas in pre-War Bohemia? Based on the simple necessities of economics and the basic human need for survival, again the answer must be yes.

To the Czechs, the changing economic pattern of the times simply implied the need to relocate within the country in order to eke out a living. If the admittedly medieval principle of Staatsrecht served to effectively thwart that impediment to the economic survival of the Czechs, then its use was as justified as the German principle of zweiteilung which it challenged.

To understand the application of these principles one must first understand the development of staatsrecht. In actuality zweiteilung was the consequence of Czech denial of German Staatsrecht, for by the mid-nineteenth century the meaning of staatsrecht had become something other than what it originally had been. 
Shortly after the Bohemian Crownlands had become merely the hereditary property of the ruling Austrian Habsburg Hausmacht, new definitions of man's place in his country and society had been formed. Emanating from revolutionary France had come the notion that one is no longer merely a subject of the almighty crown, but a citizen of the state-an equal participant subject to institutions of one's own making in a land of fellow citizens. A person became his own nobleman, subject not to a divine-rightest, high born monarch but to a community--a nation of his own kind.

This new concept fit the circumstances in the Czech lands perfectly for, having been stripped of their king and reluctant to render blind obedience to a "foreign" prince in Vienna, the Czechs instead transferred their allegience to their own community--to Checky, the Czech word for Bohemia. The national identity needed a rallying point. Czechs needed something they all shared, yet no one else had. The language provided that rallying point. Just as German nationalists about the same time had suggested that the German language should stand as the basis for unification of "Germany," so too the Czechs saw in their language the thing common to them which gave them a national identity. This same practice has been used in modern times by separatist movements such as those found in Brittany, Provence, and the Basque Country as a means to promote the self-identity of 
one's cultural uniqueness.

In Bohemia this sense of self was aided by national leaders such as Palacky who, though forced to write in the German language, showed to the czechs that they too had a culturally rich past in which they could take pride. Jan Haveleček began the Narodní Listi during the 1830's, a newspaper still published today; poetry, theater and a new interest in Czech folk culture proliferated, all promoting the use of and pride in the "national" language as a tool to further the national mission. The importance of language has been demonstrated above.

This process was further strengthened by the industrial revolution which, as has been shown, enabled hitherto disenfranchised Czechs to move up the social and political ladder. Significantly, the meteoric rise of the Czech middle class, especially after 1870, was not dependent upon "Germanizing" one's self. It was possible to be a success wholly as a Czech.

Thus, one sees, the notion of staatsrecht was applicable after the "l'etat est moi" concept was long dead because the notion of state had survived not as the property of the prince but of the people of the nation.

The notion of staatsrecht within the original, or nearly original, borders of the state hit a snag however when national aspirations became mixed with economical 
realities. The czechs could not reconcile their sociopolitical ascendancy with the pro-Austrian German-Bohemians. Nor could they apply their language theory to the Germans which, of course, would have allowed them to join their fellow Germans in Austria, or even the Weimar Republic. Instead, the Czechs rather conveniently claimed Staatsrecht in its medieval context in an attempt to deny the Germans their own staatsrecht in the modern context. What was first used as a tool to achieve Czech statehood within the Austrian Empire was now used internally to thwart GermanBohemian self-determination. The Czech argument was that the old notion of staatsrecht rendered the borders inviolable and that the whole of Bohemia should be subject to the majority will. The defensive policy of zweiteilung was seen as secessionist and therefore the Germans as spoilers of the Bohemian State.

The whole argument of the Czechs depended on their interpretation of just what the German presence represented in Bohemia. Were they fellow Bohemians who traced an ancestry back hundreds of years to pre-Habsburg times? Were they Austrians who, unlike the czechs, remained faithful to their sovereign in Vienna during the First world War and, thus, was it not actually the rebellious Czechs who were secessionists? Or were they in fact German colonists and invaders who sould be removed from the scene? The Czechs 
cerainly seemed to think the Bohemian-Germans fit the latter description when, in 1946, three million Germans were expelled from their homes and sent "back" to Germany. In fact, they could be labelled as all three, but mostly they were simply people living on their traditional land in their traditional culture and seeking through Zweiteilung the preservation of both.

The truth is, of course, that the German-Czech conflict was only finally resolved by the expulsions mentioned above. The irony is that, according to The sudetenland magazine, a bimonthly published by sudetenlanders now living in Munich, by 1973 the Czechoslovak Socialist Republic had failed, but not through lack of trying, to resettle the mountainous areas in Bohemia where the Germans had once Iived. 


\section{BIBLIOGRAPHY}

Atlas Republiky Čskoslovenské. Praze [Prague]: Česká Akademie vĕd a Uměni, Orbis Publications, 1935.

Benes, Eduard. My War Memoirs. trans. Paul Selver. London: George Allen \& Unwin Ltd., 1928.

Bonsal, Stephen. Suitors and Suppliants: The Little Nations at Versailles. New York: Prentice-Hall, Inc., 1946.

Bruegel, J. W. Czechoslovakia Before Munich: The German Minority Problem and British Appeasement Policy. London: Cambridge Unviersity Press, 1973.

Campbell, F. Gregory. Confrontation in Eastern Europe. Chicago: University of Chicago Press, 1975.

Eisenmann, Louis. Le Compromise Autro-Hongrois de 1867; Etude sur le Dualisme. Hattiesburg: Academic International, 1971 .

Gelfand, Lawrence E. The Inquiry: American Preparations for Peace, 1917-1919. New Haven: Yale University Press, 1963.

Gross, Nachum. "Consumption of Coal in Austria-Hungary 1831-1913," Journal of Economic History 31 (1971), pp. $898-916$.

Hantsch, Hugo. Geschichte Oesterreichs 1648-1918, 2 vols. Graz Wien Koeln (Graz): Verlag Styria, 1968.

Hoover, Herbert. An American Epic: Famine in Forty-five Nations: Organization Behind the Front, 1914-1923, 4 vols. Chicago: Henry Regnery Company, 1961.

House, Colonel E. M. The Intimate Papers of Colonel House. ed. Charles Seymour. 4 vols. Boston: Houghton Mifflin Company, 1928.

Jaszi, Oscar. The Dissolution of the Habsburg Monarchy. Chicago: University of Chicago Press, 1929. 
Kann, Robert A. A History of the Habsburg Empire 15281913. Berkeley: University of California Press, $\overline{1974}$.

Kann, Robert A. The Multinational Empire: Nationalism and National Reform in the Habsburg Empire 18481918. 2 vols. New York: Columbia University Press, 1950 .

Kemperer, Klemens von. Ignaz Seipel: Christian Statesman in a Time of Crisis. Princeton: Princeton University Press, 1972 .

Knoblich, Erhard J. "Gedenktafel für Rudolf Lodgman von Auel," Sudetenland 28 (1966), p. 244.

Konirch, Susan. "Constitutional Aspects of the struggle Between Germans and Czechs in the Austro-Hungarian Monarchy," Journal of Modern History 27 (1955), pp. 231-61.

KuČera, Milan and Vladimír Srb. Atlas Obuvatelstva ČSSR. Praze [Prague], Ústřední správe geodízie a kartografie. 1962 .

Lansing, Robert. The Peace Negotiations: A Personal Narrative. Boston: Houghton Mifflin Company, 1921.

Leoncini, Francesco. "Das Problem der deutschen Minderheit in Boehmen in der internationalen Politik der Jahre 1918/1919," Jahrbuch des Collegium Carolinium 13 (1972), pp. 306-381.

Lloyd-George, David. Memoirs of the Peace Conference. 2 vols. New York: Howard Fertig, 1972.

Low, Alfred D. The Anschluss Movement, 1931-1938, and the Great Powers. New York: Columbia University Press, 1985 .

Macartner, C. A. National States and National Minorities. New York: Russell and Russell, under auspices of the Royal Institute of International Affairs, London, 1934 .

Masaryk, Tomas Garrigue. The Making of a state: Memoirs and Observatrions 1914-1918. ed. Wickham Steed. New York: Frederick A. Stokes Co., 1927. 
Masaryk, Tomas Garrigue. The Meaning of Czech History. ed. Rene Wellek. Chapel Hill: University of North Carolina Press, 1974 .

Matis, Herbert, Karl Bachinger. Die Wirtschafliche Entwicklung. vol. 1 of Die Habsburgermonarchie 18481918. 4 vols. ed. Alois Brusatti. Wien [Vienna]: Verlag der Oesterreichischen Akademie der Wissenschaften, 1973.

Mitchell, B. R. European Historical Statistics. New York: Columbia University Press, 1975.

Molisch, Paul. Die Sudetendeutche Freiheits-Bewegung in den Jahren 1918-1919. Wien [Vienna]: UniversitaetsVerlags-Buchhandlung, 1932.

Mommsen, Hans. Die Sozialdemokratie und die Nationalitaetenfrage im habsburgischen Vielvoelkerstaat. I. "Das Ringen um die supranationale Integration der zisleithanischen Arbeiterbewegung (1867-1907). Wien [Vienna]: Europa-Verlag, 1973.

Myers, Duane P. "Berlin versus Vienna: Disagreements about Anschluss in winter of 1918-1919," Central European History 5 (1972), pp. 150-175.

Naumann, Friedrich. Central Europe. Trans. Christabel M. Meredith. New York: Alfred A. Knopf, 1917.

Nicholson, Harold. Peacemaking 1919. New York: Harcourt, Brace and Company, 1939.

Opitz, Alfred. "Boehmen und die deutschboehmische Frage in der ersten Phase der Herausbildung des tschechischen Nationalstaates in Jahre 1918: Nach Berichten der Saechsischen Gesandtschaft in Wien," Bohemian Jahrbuch des Collegium Carolium 17 (1976), pp. 193-208.

Pech, Stanley $Z$. The Czech Revolution of 1848. Chapel Hill: University of North Carolina, 1969.

Perman, D. The Shaping of the Czechoslovak State: Diplomatic History of the Boundaries of Czechoslovakia, 1914-1920. Leiden: E. J. Brill, 1962.

Pounds, J. G. Eastern Europe. Chicago: Aldine Publishing Compahy, 1969 .

Prager Tagblatt. January 1918 - March 1919. Prague. 
Schmid-Egger, Hans. "The Sudeten German Renewal Movement in the Twenties of This Century," Sudetenland 27 (1985), pp. 325-326.

Seton-Watson, R. W. A History of the Czechs and Slovaks. Hamden: Archon Books, 1965.

Seton-Watson, R. W. Masaryk in England. Cambridge: University Press, 1943.

Sugar, Peter F. "The Rise of Nationalism," Austrian History Yearbook 3 (1967), pp. 91-120.

Sutter, Berthold. DieBadenisichen Sprachenverordnungen von 1897: Ihre Genesis und ihre Auswirkungen vornehmlich auf die inneroesterreichischen Alpenlaender. 2 vols. Graz-Koeln: Verlag Herman Boehlaus Nachf., 1965.

Tacitus, Cornelius. The Agricola and the Germania. Trans. H. Mattingly. New York: Penguin, 1971.

Temperley, Harold W. V. A History of the Paris Peace Conference of Paris. 6 vols. London: Henry Frowde and Hodder \& Stoughton under auspices of the Institute of International Affairs, 1921.

United States Government, Department of State. Foreign Relations of the United States. Lansing Papers 19141920. 2 vols. Washington: Government Printing Office, 1939 .

United States Government, Department of State. Foreign Relations of the United States Paris Peace Conference. 13 vols. Washington: Government Printing office, 1942 .

United States Government, Department of State. Papers Relating to the Foreign Relations of the United States 1917-1919. Washington: Government Printing Office, $1926-34$.

Wallace, William V. Czechoslovakia. Boulder: Westview Press, 1976.

Whiteside, Andrew G. Austrian National Socialism Before 1918. The Hague: M. Nijhoff, 1962 .

Wiskemann, Elizabeth. Czechs and Germans: A Study of the Struggle in the Historic Provinces of Bohemia and Moravia. London: Exford University Press under auspices of the Royal Institute of International Affairs, 1938. 
APPENDIX 


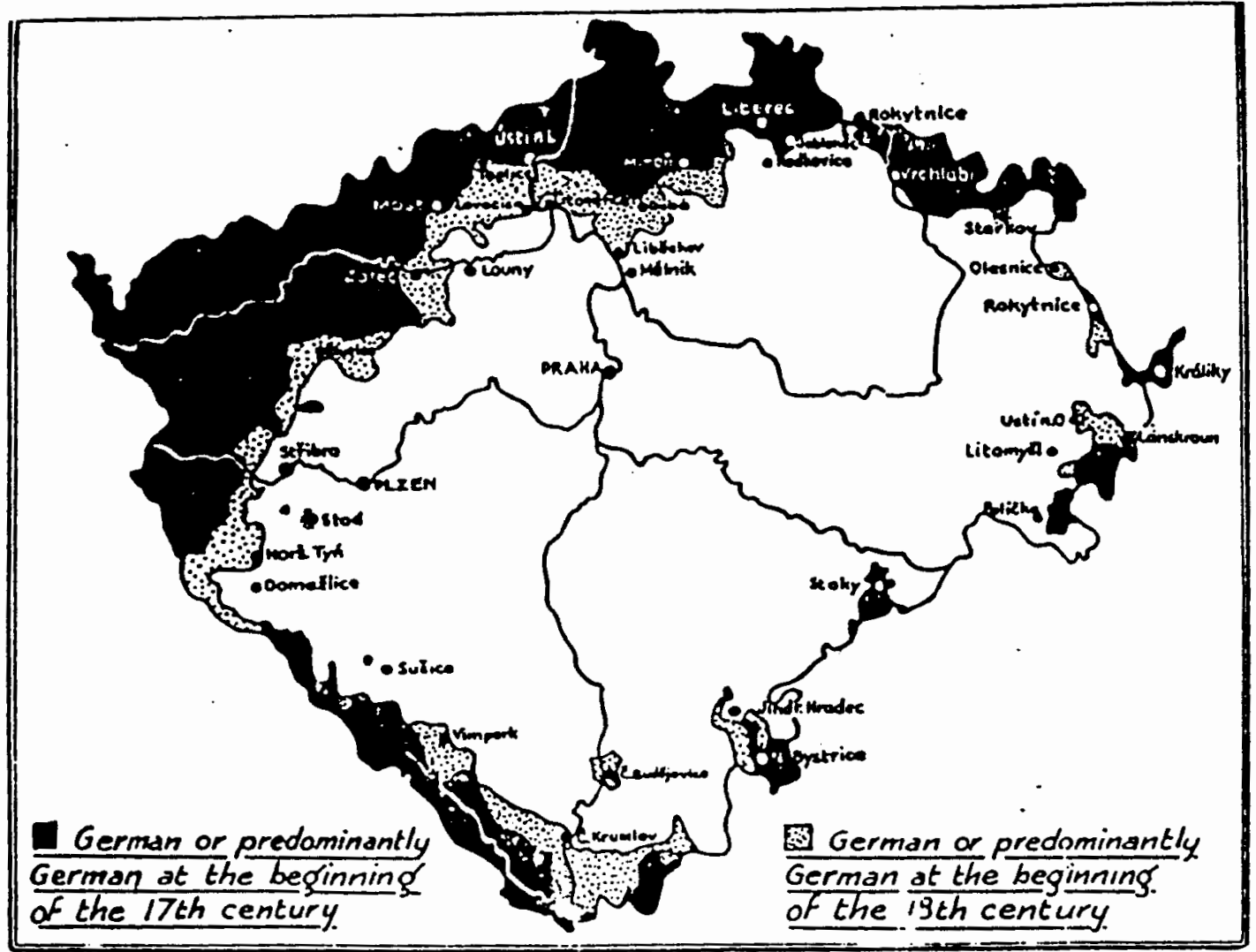

Map 1. Long Established German Areas in the Crownland of Bohemia. (Based on Czechs and Germans, by Elizabeth Wiskermann.) 


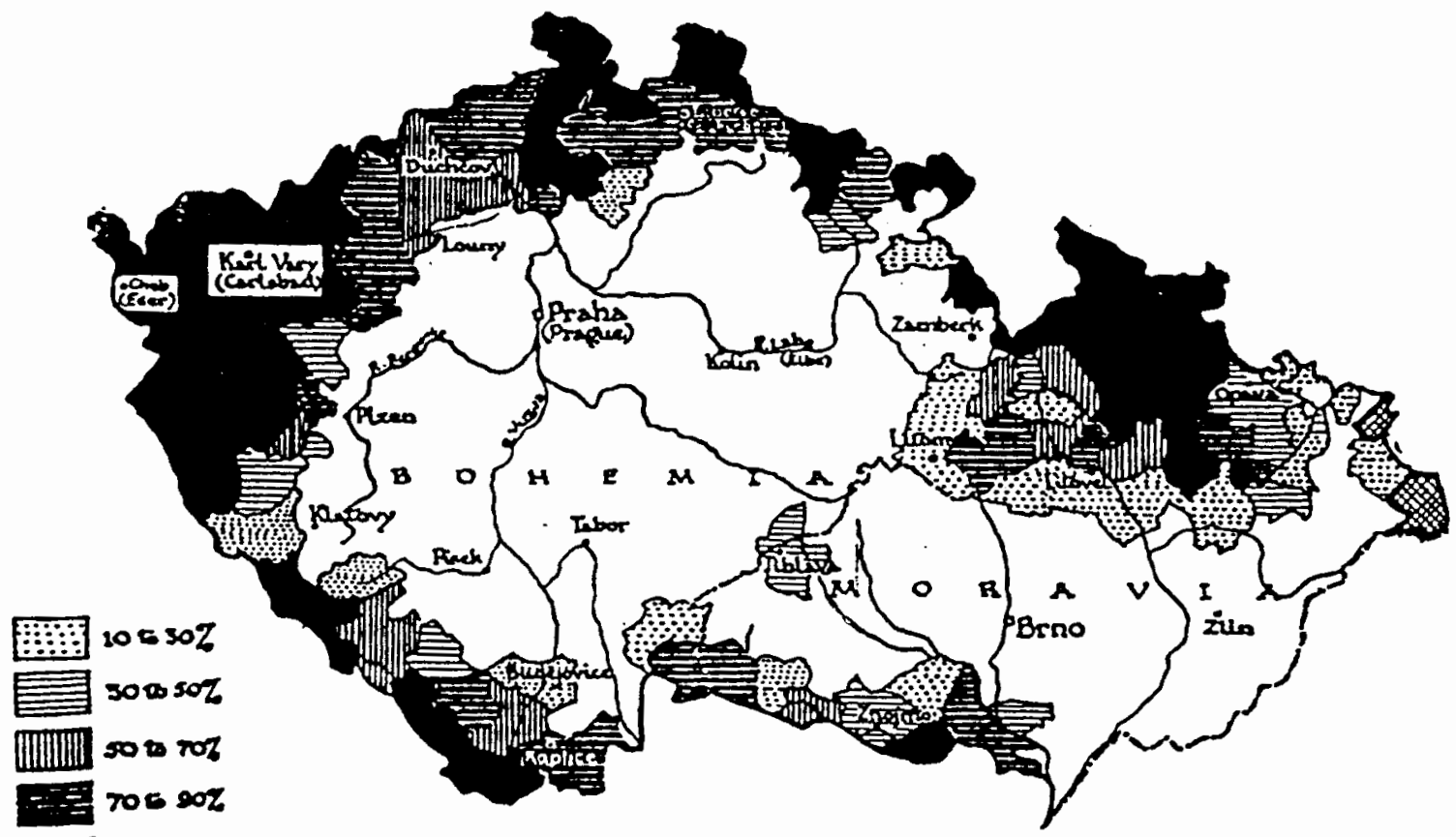

$100 \div 100 Z$

Germase

Map 2. German Population Distribution and Density in

Early Twentieth Century. (Based on Czechoslovak source. The German Problem in Czechoslovakia, by Josef Chmelar.)

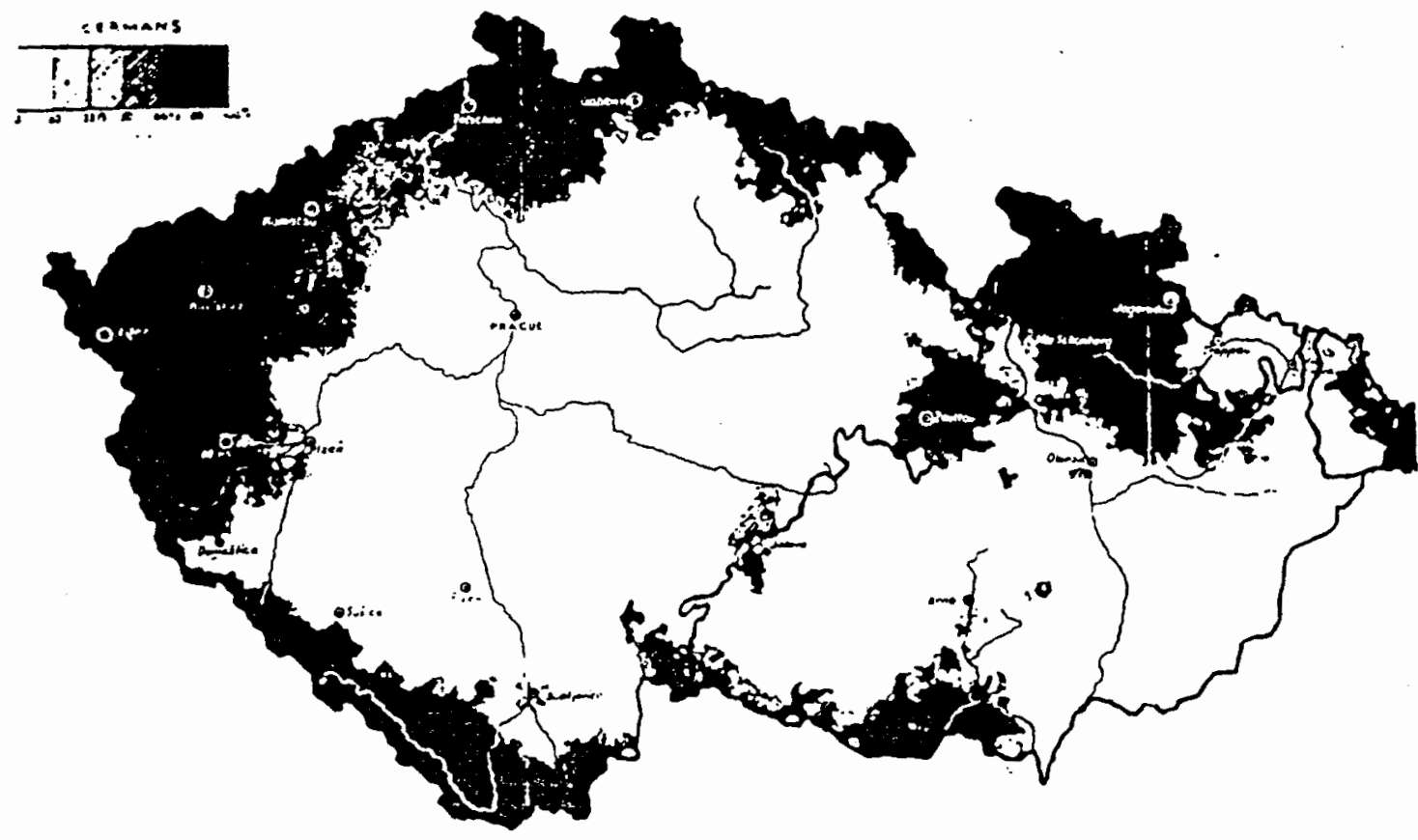

(Based on German source. Die Tschechoslawakei in Spiegel der Statistik, by Erwin Winkler.) 


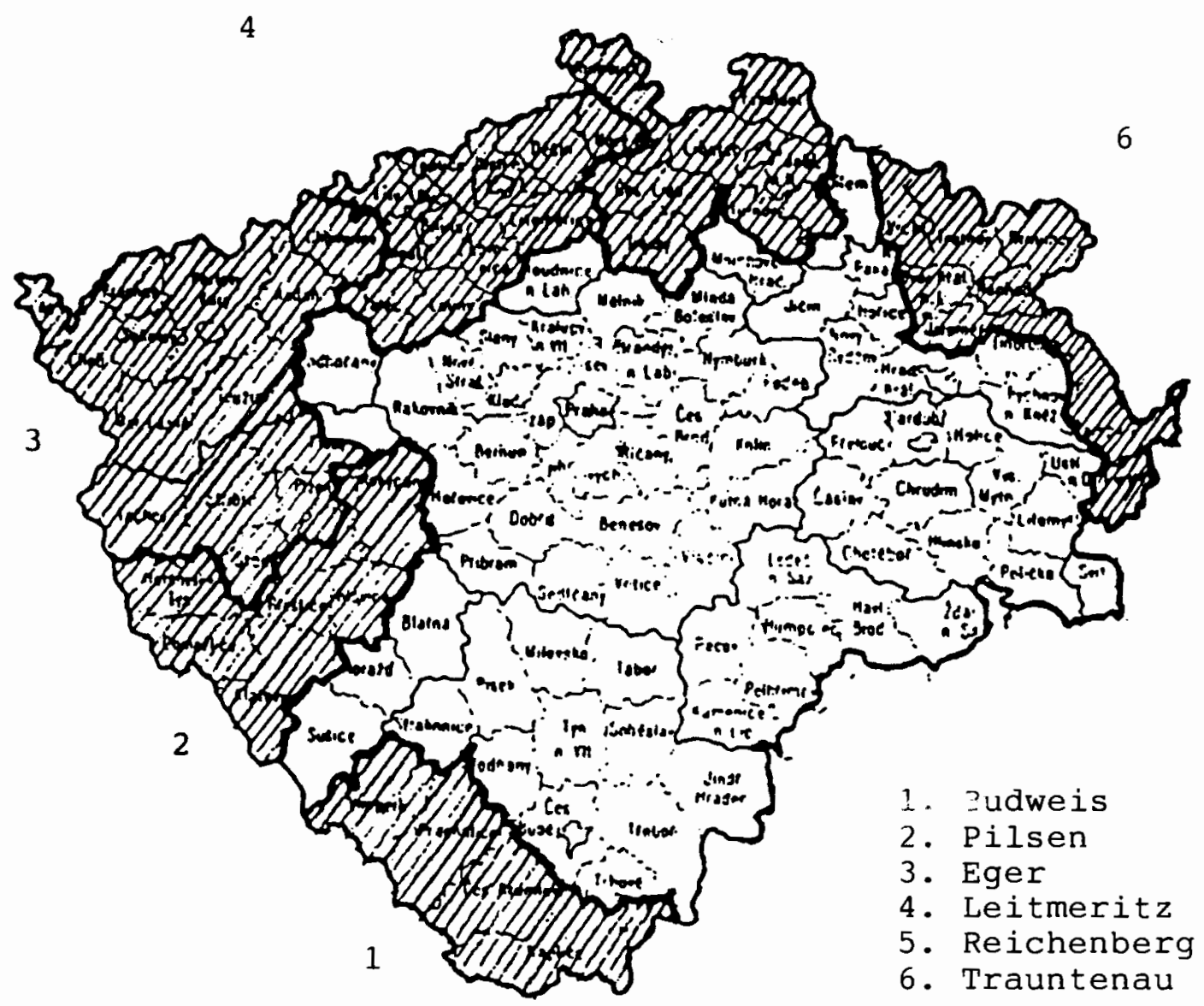

Map 3. The Nationalist Union's German Proposal of May 1918 for the Ethnic Administrative Partition of the crownland of Bohemia. A later version dropped the city of Pilsen attaching the German Bezirke to the Eger Kreis. (Printed in the Prager Tagblatt, May 22. $1 \overline{918.1}$ 

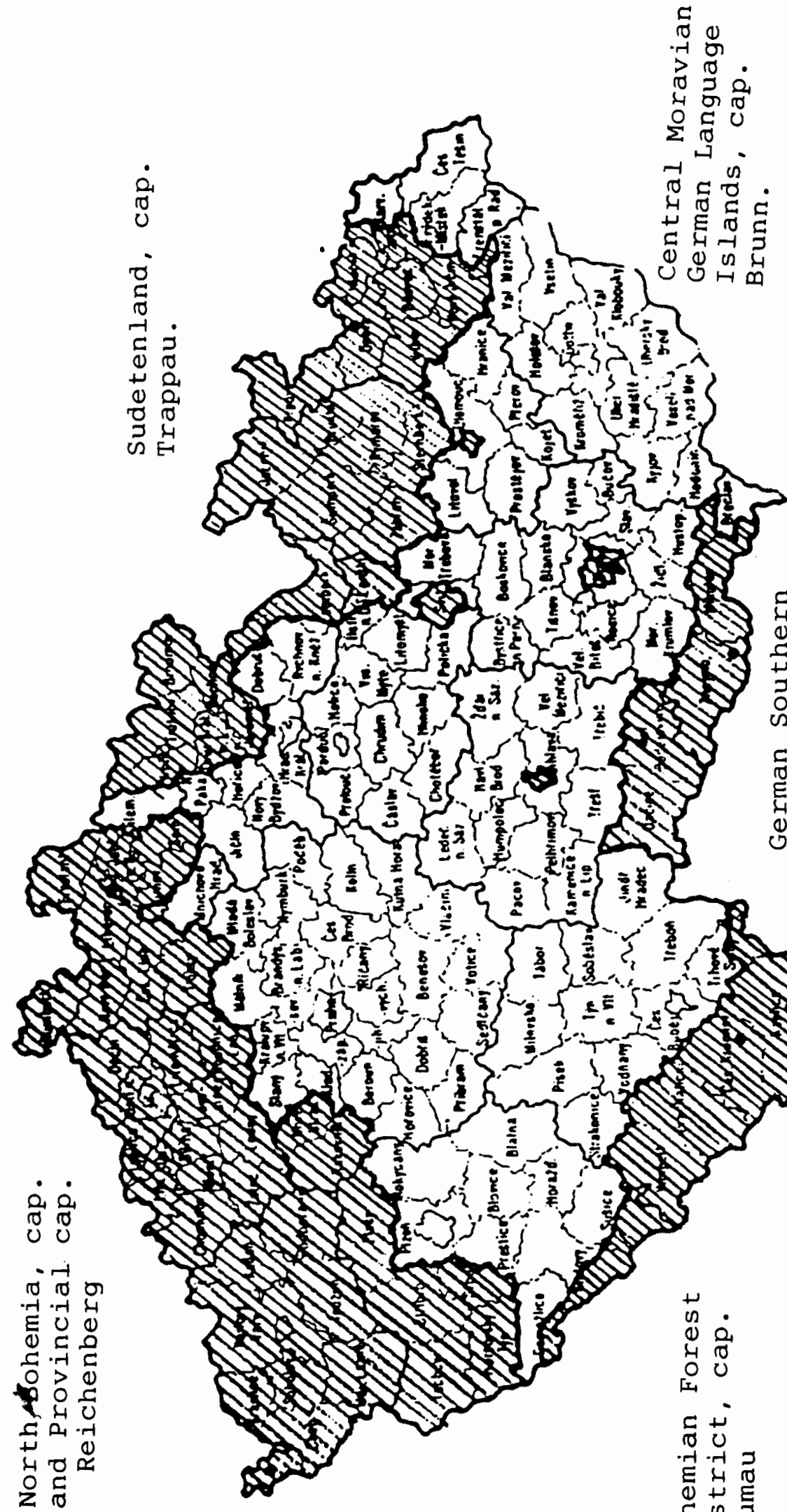

5) (3)

- 15

1
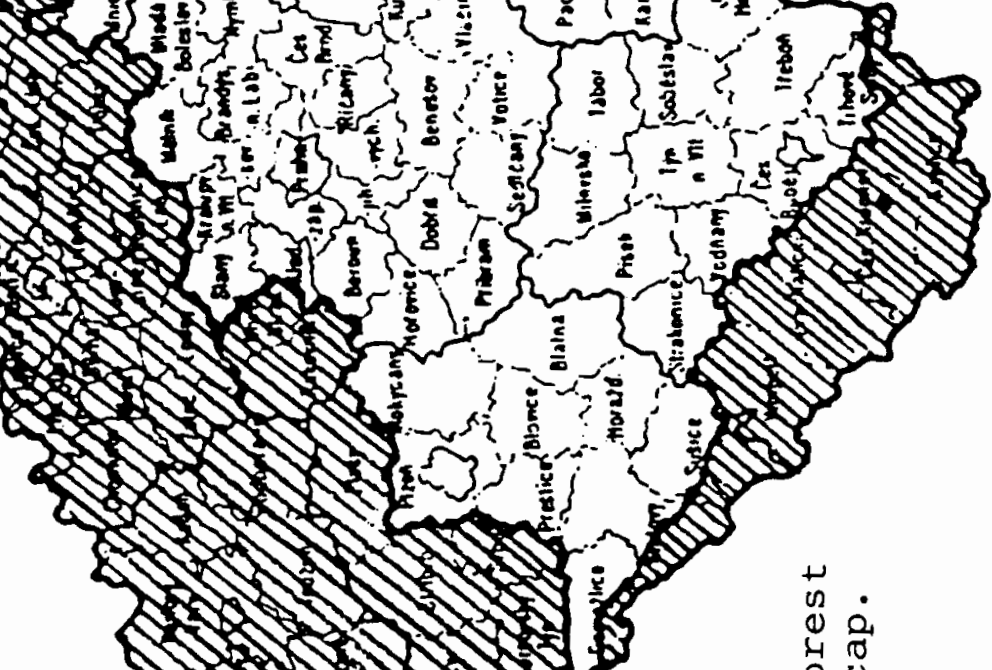

STIN $1 \times 15:$

S. $\times 1 \times$

150

580

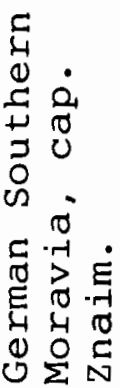

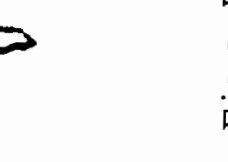

㟧

(1)

E苞E

Q

टण 4

$\rightarrow=00$ व

n

n 20 -

4 त 10 in

क.

(1) of 0

$>00=0$

- $ब$ बा

工 厌

थ 0 . . . व

苛年出

ᄃ

. $\rightarrow 000$

$\sigma^{\Sigma} E_{3}$

- $100+0$

E 204

E

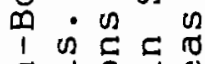

ट $=0.70$

E

द्4 0 .

$\otimes$ \& $\varepsilon$ T

U $x$.

4 O० 0

0 Q 400

0.त थत्

U स त

ट

- 40

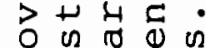

म. त की

A $ᄃ \backsim \otimes 0$

(1)

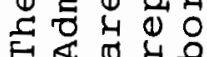

0
0

$\dot{0}$
인

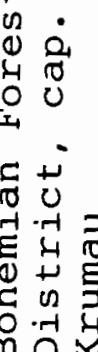

